\title{
The western diet and lifestyle and diseases of civilization
}

\author{
This article was published in the following Dove Press journal: \\ Research Reports in Clinical Cardiology \\ 8 March 201I \\ Number of times this article has been viewed
}

\section{Pedro Carrera-Bastos ${ }^{1}$ Maelan Fontes-Villalba' James H O'Keefe ${ }^{2}$ Staffan Lindeberg' Loren Cordain ${ }^{3}$}

'Center for Primary Health Care Research, Faculty of Medicine at Lund University, Malmö, Sweden; ${ }^{2}$ Mid America Heart and Vascular Institute/University of MissouriKansas City, Kansas City, Missouri, USA; ${ }^{3}$ Department of Health and Exercise Science, Colorado State University, Fort Collins, Colorado, USA
Correspondence: Pedro Carrera-Bastos R. Gorgel do Amaral, No. 5, I E; Lisbon I250-I I9, Portugal Tel +35I 967088799

Email pedro.carrera_bastos@med.lu.se
Abstract: It is increasingly recognized that certain fundamental changes in diet and lifestyle that occurred after the Neolithic Revolution, and especially after the Industrial Revolution and the Modern Age, are too recent, on an evolutionary time scale, for the human genome to have completely adapted. This mismatch between our ancient physiology and the western diet and lifestyle underlies many so-called diseases of civilization, including coronary heart disease, obesity, hypertension, type 2 diabetes, epithelial cell cancers, autoimmune disease, and osteoporosis, which are rare or virtually absent in hunter-gatherers and other non-westernized populations. It is therefore proposed that the adoption of diet and lifestyle that mimic the beneficial characteristics of the preagricultural environment is an effective strategy to reduce the risk of chronic degenerative diseases.

Keywords: Paleolithic, hunter-gatherers, Agricultural Revolution, modern diet, western lifestyle and diseases

\section{Introduction}

The physical activity, sleep, sun exposure, and dietary needs of every living organism (including humans) are genetically determined. This is why it is being increasingly recognized in the scientific literature, especially after Eaton and Konner's ${ }^{1}$ seminal publication in 1985, that the profound changes in diet and lifestyle that occurred after the Neolithic Revolution (and more so after the Industrial Revolution and the Modern Age) are too recent on an evolutionary time scale for the human genome to have fully adapted. ${ }^{1-27}$

In fact, despite various alleles being targets of selection since the Agricultural Revolution, ${ }^{28-42}$ most of the human genome comprises genes selected during the Paleolithic Era ${ }^{43}$ in Africa, ${ }^{43-59}$ a period that lasted from about 2.5 million years ago to 11,000 years ago. ${ }^{14}$ Indeed, anthropological and genetic studies suggest that all human beings living in Europe, Asia, Oceania, and the Americas share a common African Homo sapiens ancestor. ${ }^{47-57}$ This concept is corroborated by data showing that there is less genetic diversity throughout the world's non-African population than there is within Africa itself. ${ }^{44-46,53,57,58}$

Moreover, many of the selective pressures underlying these postagriculture alleles were not induced by changes in sleep, exercise, and diet but rather by pathogens, fatal diseases, and harsh environments, ${ }^{28-31,37-39}$ with a few key exceptions. ${ }^{41,42}$ One of those exceptions pertains to alleles of the LCT gene (which codes for the enzyme lactasephlorizin hydrolase [LPH]) that give rise to the phenotype of adult lactase persistence (ALP). ${ }^{60}$ These LPH-encoding alleles were initially selected in populations with a long history of milk and dairying, such as north-western Europeans and some sub-Saharan 
African and Bedouin pastoralists. Today, ALP occurs in about $35 \%$ of the world's population. ${ }^{60}$

The impetus for these genetic changes was not to increase longevity and resistance to chronic degenerative diseases but rather to increase the probability of survival and reproductive success. ${ }^{27,61,62}$ Occasionally, mutations that had positive survival and reproductive value sometimes also caused adverse health effects in the postreproductive years., 27,61,62 Furthermore, single gene mutations, although relevant for physicians when treating an individual patient, are imperfect models to prevent chronic degenerative diseases whose clinical symptoms normally affect the postreproductive years and involve numerous genes. ${ }^{61}$

Importantly, 11,000 years represent approximately 366 human generations, ${ }^{63}$ which comprise only $0.5 \%$ of the history of the genus Homo (Table 1). ${ }^{14,63-65}$ Indeed, the Industrial Revolution and the Modern Age, which mark the beginning of the western lifestyle, represent only seven and four human generations, respectively (Table 1), ${ }^{14,63-65}$ and were marked by rapid, radical, and still ongoing changes in lifestyle and diet, ${ }^{14,65}$ coupled with improved public health measures that greatly reduced mortality in the prereproductive years (and hence largely eliminated impaired reproductive fitness as a selection pressure). ${ }^{62,66}$ As such, it is highly unlikely that genetic adaptations that allow us to thrive on a western diet and lifestyle have occurred.

\section{Health status of preagriculture traditional populations}

The idea that modern Homo sapiens are still adapted to an ancestral environment is reinforced by data showing that hunter-gatherers, and other populations minimally affected by modern habits, exhibit superior health markers, body composition, and physical fitness compared with industrialized populations, including:

1. Low blood pressure in hunter-gatherers and horticultural-

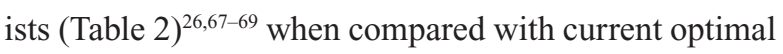
values defined by health institutions $(<120 \mathrm{~mm} \mathrm{Hg}$

Table I Historical milestones in human generations ${ }^{14,63-65}$

\begin{tabular}{lll}
\hline Historical milestones & Generations & \% total \\
\hline Homo habilis & 76,667 & 100.0 \\
Homo erectus & 60,000 & 78.2 \\
Modern Homo sapiens & 6666 & 8.7 \\
Neolithic Revolution & 366 & 0.48 \\
Industrial Revolution & 7 & 0.009 \\
Food industry (junk food) and & 4 & 0.005 \\
physical inactivity (Modern Age) & & \\
\hline
\end{tabular}

Table 2 Systolic blood pressure (SBP) and diastolic blood pressure (DBP) at age 40-60 years in hunter-gatherers and horticulturalists $(\mathrm{mm} \mathrm{Hg})^{26,67-69}$

\begin{tabular}{llllll}
\hline Population & Men & & & Women & \\
\cline { 2 - 3 } \cline { 5 - 6 } & SBP & DBP & & SBP & DBP \\
\hline Bushmen & 108 & 63 & 118 & 71 \\
Yonomamo & 104 & 65 & 102 & 63 \\
Xingu & 107 & 68 & 102 & 66 \\
Kitava & 113 & 71 & 121 & 71 \\
\hline
\end{tabular}

and $<80 \mathrm{~mm} \mathrm{Hg}$ for systolic blood pressure and diastolic blood pressure, respectively) ${ }^{70}$

2. Lack of association between blood pressure and age in hunter-gatherers (Table 3$)^{69}$ and horticulturalists ${ }^{68}$ compared with in North Americans and Swedes ${ }^{26,68,70}$

3. Persisting excellent insulin sensitivity among middleaged and older individuals in non-westernized traditional populations that maintain their ancestral lifestyle $26,71-81$

4. Lower fasting plasma insulin concentrations and higher insulin sensitivity (measured by the Homeostatic Model Assessment [HOMA] index) in the horticulturalists of Kitava (Papua New Guinea) compared with in healthy Swedes (Figures 1 and 2, respectively) ${ }^{74}$

5. Lower fasting plasma leptin in the horticulturalists of Kitava and the Ache hunter-gatherer Indians of Paraguay compared with in healthy Swedes ${ }^{82}$ (Figure 3) and North American male distance runners ${ }^{83}$ (Figure 4), respectively

6. Lower body mass index (BMI) in hunter-gatherers, traditional pastoralists, and horticulturalists ${ }^{26}$ compared with in westerners. ${ }^{26,84}$ For instance, as observed by Lindeberg, ${ }^{26}$ in Kitava, $87 \%$ of men and $93 \%$ of women aged $40-60$ years had a BMI below $22 \mathrm{~kg} / \mathrm{m}^{2}$ and not a single individual in this age group was overweight or obese ${ }^{26}$

7. Lower waist $(\mathrm{cm}) /$ height $(\mathrm{m})$ ratio in the horticulturalists of Kitava compared with in healthy Swedes $(\text { Figure 5) })^{82}$

8. Lower tricipital skinfold ( $\mathrm{mm})$ in hunter-gatherers compared with in healthy Americans ${ }^{67}$ (Figure 6)

Table 3 Systolic blood pressure and diastolic blood pressure in Yanomamo Indians $(\mathrm{mm} \mathrm{Hg})^{69}$

\begin{tabular}{lll}
\hline Age (years) & Men & Women \\
\hline $0-9$ & $93 / 59$ & $96 / 62$ \\
$10-19$ & $108 / 67$ & $105 / 65$ \\
$20-29$ & $108 / 69$ & $100 / 63$ \\
$30-39$ & $106 / 69$ & $100 / 63$ \\
$40-49$ & $107 / 67$ & $98 / 62$ \\
$50+$ & $100 / 64$ & $106 / 64$ \\
\hline
\end{tabular}


9. Greater maximum oxygen consumption $\left(\mathrm{VO}_{2} \max \right)$ in hunter-gatherers and traditional pastoralists compared with in average Americans ${ }^{67}$ (Figure 7)

10. Better visual acuity in hunter-gatherers and other traditional populations minimally affected by western habits compared with in industrialized populations ${ }^{85}$

11. Better bone health markers in hunter-gatherers compared with in western populations and even traditional agriculturalists ${ }^{26,86-98}$

12. Lower fracture rates in non-westernized populations compared with in western populations. ${ }^{26,96-99}$

Another line of evidence supporting the superior health markers of hunter-gatherers and other traditional populations comes from the historical records of explorers, adventurers, and frontiersmen, which invariably described the populations they encountered as being healthy, lean, fit, and free of the signs of chronic degenerative diseases. ${ }^{26}$ But perhaps even more important than these observations are the medical and anthropological reports showing a low incidence of chronic degenerative diseases such as metabolic syndrome and type 2 diabetes, ${ }^{26,67,73,74,100}$ cardiovascular disease (CVD), ${ }^{26,65,67,68,100-112}$ cancer, ${ }^{26,67,113-118}$ acne,${ }^{119}$ and even myopia ${ }^{85}$ in hunter-gatherers, traditional pastoralists, and horticulturalists compared with in western populations $\mathrm{s}^{26,65,67,85,100,108,109,113,114,119,120}$ and even ancient Egyptians ${ }^{67,114,121-123}$ and medieval Europeans. ${ }^{114}$

\section{Counterarguments}

It has been argued that traditional populations may have been genetically protected against the chronic degenerative diseases that occur in industrialized countries, yet when non-westernized individuals adopt a more contemporary lifestyle, their risk for chronic degenerative diseases is similar or even increased compared with modern populations. 26,67,78-80,108,109,124-144 Further, when they return to their original traditional lifestyle, many disease

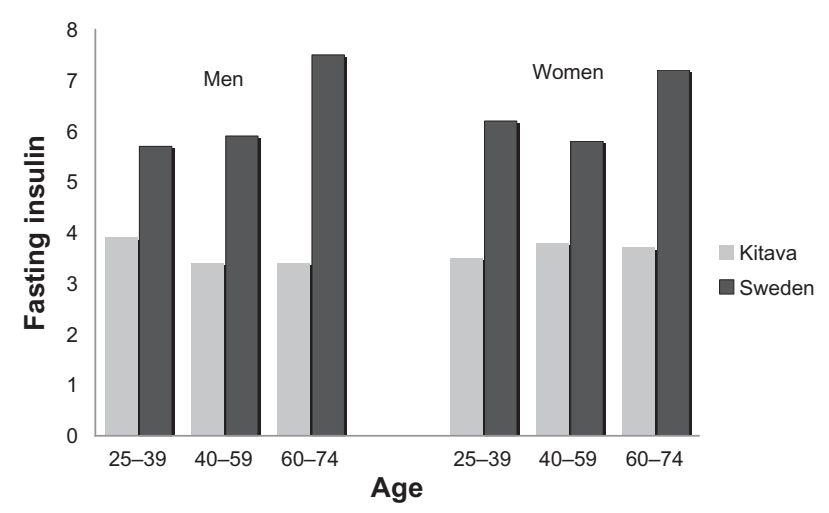

Figure I Fasting plasma insulin $(\mathrm{IU} / \mathrm{mL})$ in Kitava horticulturalists versus in healthy Swedes. ${ }^{74}$ markers or symptoms return to normal. ${ }^{81,145}$ These data demonstrate that the superior health markers, body composition, and physical fitness of hunter-gatherers and other populations minimally affected by modern habits are not due primarily to genetics but first and foremost to the environment. These studies also indicate that few or no genetic adaptations have occurred to protect any population from chronic diseases that are elicited by modern diet and lifestyles.

Indeed, two different individuals when exposed to the same modern environment (eg, western diet, physical inactivity, insufficient and inadequate sleep, chronic psychological stress, insufficient or excessive sun exposure, use of recreational drugs, smoking, pollution) will probably express a suboptimal phenotype. ${ }^{27,65,146,147}$ This may or may not be considered pathological, depending on genetic variants (eg, haplotypes, single nucleotide polymorphisms, microsatellites, simple sequence repeats, insertion/deletion, copy number variations) and differences in gene expression regulation (such as epigenetic variations). ${ }^{27,62,146,148}$

Another common counterargument is the short average life expectancy at birth of hunter-gatherers. The problem with this marker is that it is influenced by fatal events (eg, accidents, warfare, infections, exposure to the elements) and childhood mortality. Today, average life expectancy is higher not because of a healthier diet and lifestyle but owing to better sanitation, vaccination, antibiotics, quarantine policies, medical care, political and social stability, and less physical trauma. ${ }^{66}$ Moreover, Gurven and Kaplan, ${ }^{149}$ in a recent assessment of the mortality profiles of extant hunter-gatherers for which sufficient high-quality demographic data exist, concluded that "modal adult life span is $68-78$ years, and that it was not uncommon for individuals to reach these ages".

Of more importance, these individuals reached age 60 years or beyond without the signs and symptoms of chronic degenerative diseases that afflict the majority of the elderly in industrialized countries. ${ }^{66}$ Furthermore, in western countries, various illnesses and conditions, such as obesity, type 2 diabetes, gout, hypertension, coronary heart disease (CHD), and epithelial cell cancers, which are rare or virtually absent in hunter-gatherers, horticulturalists, and traditional pastoralists, are now increasing in younger age groups..$^{26,64-66}$ Finally, the fossil record suggests that when hunter-gatherer populations made the transition to an agricultural pattern of subsistence, their health status and lifespan decreased. ${ }^{26,109,150}$

\section{The ancestral environment}

With the help of anatomical, biomechanical, and isotopic analyses of various hominin skeletons, the archaeological 

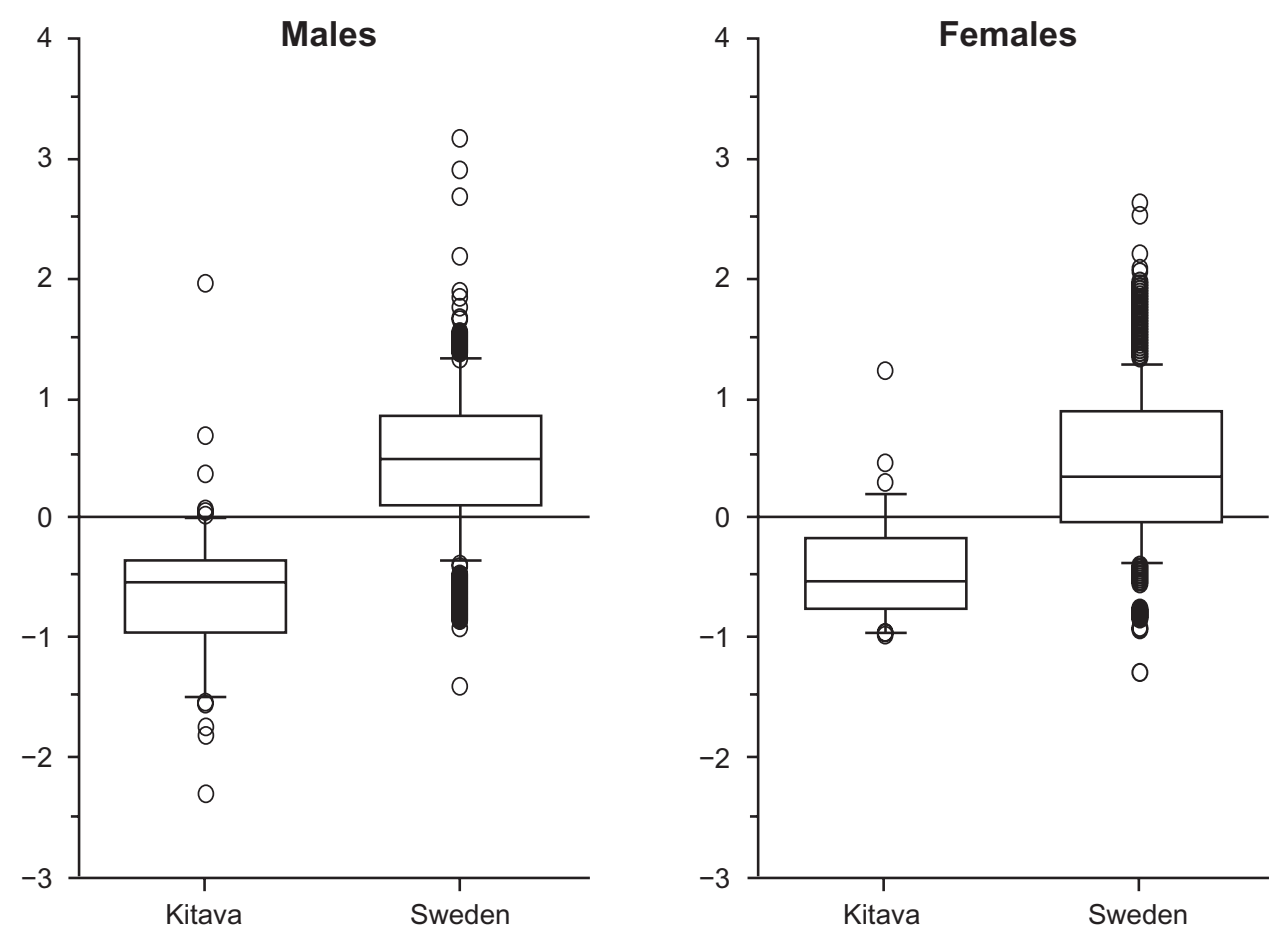

Figure 2 Homeostatic Model Assessment Index in Kitava horticulturalists versus in healthy Swedes. ${ }^{74}$

and geological evaluation of their habitats, and ethnographic studies of various hunter-gatherer societies (whose diet and lifestyle resembled the Palaeolithic diet and lifestyle), it was concluded $^{38,61,64,65,108,151-157}$ that, despite the existence of different diets and lifestyles, which varied due to differences in geography, ecological niche, season, and glaciations, they all had the following characteristics:

- Regular sun exposure ${ }^{38,151}$ (except for the Inuit, whose very high intake of vitamin D3 from fish and marine mammals ${ }^{158,159}$ may have rendered the lack of ultravioletstimulated cutaneous vitamin D synthesis less relevant)

- Sleep patterns in synch with the daily variation in light exposure $^{152}$

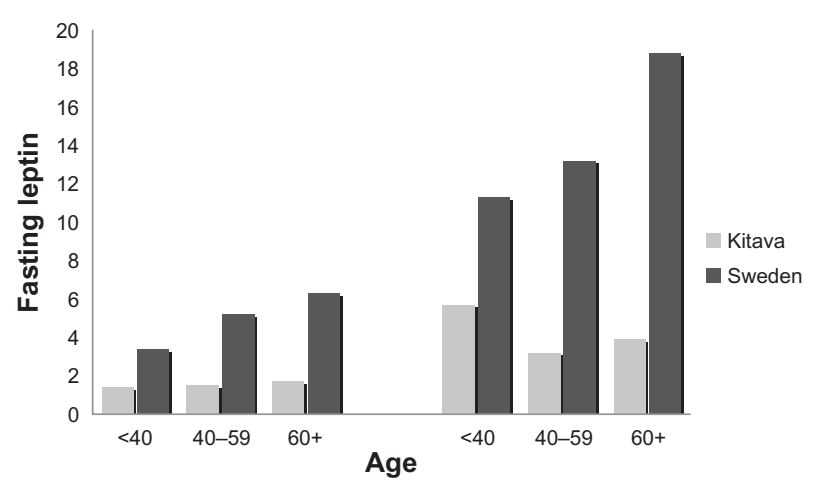

Figure 3 Fasting plasma leptin $(\mathrm{ng} / \mathrm{mL})$ in Kitava horticulturalists versus in healthy Swedes. ${ }^{82}$
- Acute as opposed to chronic stress ${ }^{160}$

- Regular physical activity, as this was required to obtain food and water, to escape from predators, for social interaction, and to build shelters ${ }^{146,147,153}$

- Lack of exposure to man-made environmental pollutants $^{160}$

- Universal fresh (generally unprocessed) food sources as depicted in Table 4. . $^{14,64,65,154,155,157}$

\section{The Neolithic and industrial revolutions and their consequences}

The Agricultural Revolution began about 11,000 years ago in the Middle East, later spread to other regions of the

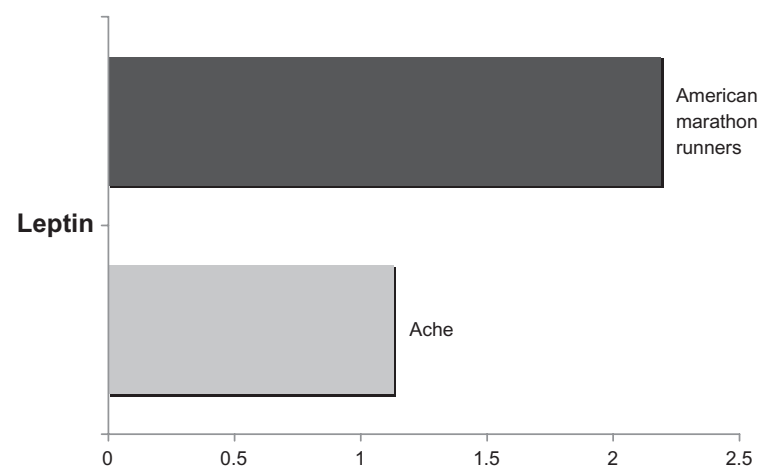

Figure 4 Fasting plasma leptin $(\mathrm{ng} / \mathrm{mL})$ in Ache Indians versus in American marathon runners. $^{83}$ 


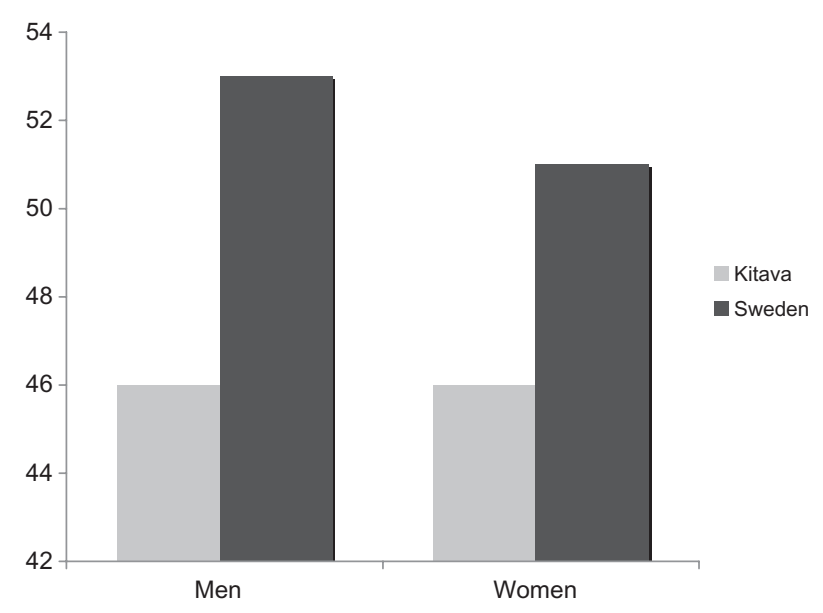

Figure 5 Waist circumference $(\mathrm{cm})$ /height $(\mathrm{m})$ in Kitava horticulturalists versus in healthy Swedes. ${ }^{82}$

globe, ${ }^{14,65,154}$ and drastically altered the diet and lifestyle that had shaped the human genome for the preceding 2 million plus years. Some of the more significant dietary changes were the use of cereal grains as staple foods, the introduction of nonhuman milk, domesticated meats, legumes and other cultivated plant foods, and later widespread use of sucrose and alcoholic beverages. ${ }^{14,65}$

Nevertheless it was the Industrial Revolution (with the widespread use of refined vegetable oils, refined cereal grains, and refined sugars ${ }^{14,65}$ and the Modern Age (with the advent of the "junk food" industry, generalized physical inactivity, introduction of various pollutants, avoidance of sun exposure, and reduction in sleep time and quality coupled with increased chronic psychological stress $)^{14,38,65,146,152,153,160}$ that brought about the most disruptive and maladaptive changes, which may have serious pathophysiological consequences. For instance, chronic psychological stress, environmental pollution, and smoking are associated with low-grade chronic inflammation, ${ }^{161-165}$ which is one of the main causes of insulin resistance. ${ }^{161,164,165}$

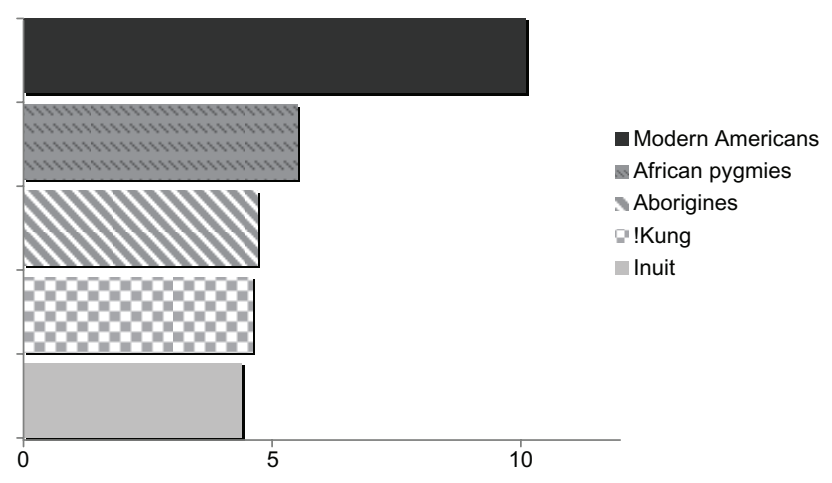

Figure 6 Tricipital skinfold $(\mathrm{mm})$ in several populations. ${ }^{67}$

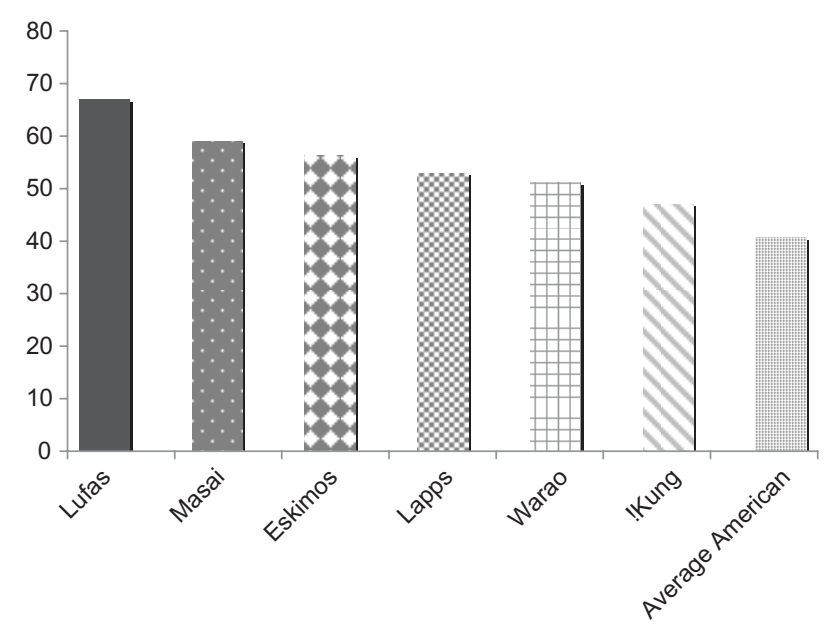

Figure 7 Maximum oxygen consumption in various populations $(\mathrm{mL} / \mathrm{kg} / \mathrm{min}){ }^{67}$

Moreover, low-grade chronic inflammation is involved in all stages of the atherosclerotic process ${ }^{166}$ and is being increasingly recognized as a universal mechanism in various chronic degenerative diseases, such as autoimmune diseases, certain cancers, neuropsychatric diseases, and osteoporosis. $^{27,65,160,167}$ Furthermore, some environmental pollutants, including pesticides and various industrial chemicals, may act as endocrine disruptors, hence being suspected of playing a causal role in hormone-dependent cancers (such as breast and prostate cancer), ${ }^{168}$ insulin resistance ${ }^{169}$ and type 2 diabetes, ${ }^{169,170}$ obesity, ${ }^{171}$ and CVD. ${ }^{170,172}$

Insufficient sleep (fewer than 6 hours per 24-hour day) is also associated with low-grade chronic inflammation and worsening insulin resistance, ${ }^{165,173}$ as well as increased risks for obesity, type 2 diabetes, and CVD. ${ }^{165,174,175}$ This information is relevant in light of a recent cross-sectional

Table 4 Foods consumed during the Paleolithic Era ${ }^{14,64,65,154,155,157}$

\begin{tabular}{ll}
\hline Foods available & Foods not available \\
\hline $\begin{array}{l}\text { Insects, fish, shellfish and other } \\
\text { marine animals, reptiles, birds, } \\
\text { wild terrestrial mammals and eggs }\end{array}$ & $\begin{array}{l}\text { Dairy (except for human milk } \\
\text { during weaning) }\end{array}$ \\
$\begin{array}{l}\text { Plant leaves, seaweed, sea } \\
\text { grasses and algae }\end{array}$ & $\begin{array}{l}\text { Cereal grains (with the exception } \\
\text { of occasional intake in the upper } \\
\text { Palaeolithic) }\end{array}$ \\
Roots & $\begin{array}{l}\text { Legumes (except certain varieties } \\
\text { that were consumed seasonally) } \\
\text { Iubers }\end{array}$ \\
$\begin{array}{l}\text { Isolated sugar } \\
\text { Isolated oils }\end{array}$ \\
Auts and seeds & $\begin{array}{l}\text { Alcohol } \\
\text { Honey (occasional intake) }\end{array}$ \\
& $\begin{array}{l}\text { Refined salt (even sea salt would } \\
\text { be available only for shore-based } \\
\text { populations who may have dipped }\end{array}$ \\
& their food in sea water) \\
\hline
\end{tabular}


population-based study showing that $28 \%$ of US adults sleep 6 or less hours per 24-hour period. ${ }^{175}$ Moreover, social and work pressures, as well as exposure to artificial light at atypical biologic times (a very recent phenomenon in human evolutionary history), induce a disruption of the normal circadian rhythm, which is believed to play a key role in various diseases. ${ }^{176}$ As Vgontzas et al ${ }^{173}$ point out: "the idea that sleep or parts of it are optional should be regarded with caution".

Perhaps even more important is the chronic vitamin D deficiency brought about by novel cultural and geographical changes in human behavior. As Homo sapiens left equatorial Africa and begun to occupy higher latitude regions, where the proportion of ultraviolet $B$ wavelengths is decreased and of ultraviolet A vitamin D-destructive wavelengths is increased, previtamin D3 production became compromised (especially in the winter time). ${ }^{38}$ This may have increased the incidence of rickets, muscle weakness, and bacterial and viral infections, which impaired reproductive fitness and increased early mortality. ${ }^{38}$ Thus, it has been hypothesized that these were the main selective pressures for lighter skin pigmentation, which is a recent adaptation in human evolutionary history. ${ }^{38}$ Although natural selection for lighter skin pigmentation may have reduced the prevalence of rickets, muscle weakness, and bacterial and viral infections, it may not have assured an optimal vitamin D status, given the many functions now attributed to 1,25-dihydroxyvitamin $\mathrm{D}(1,25[\mathrm{OH}] 2 \mathrm{D})$, the existence of vitamin $\mathrm{D}$ receptors, and the occurrence of $1,25[\mathrm{OH}] 2 \mathrm{D}$ synthesis in various cells. ${ }^{177}$

Today, vitamin D status is further compromised by migrations of people with dark skin (adapted to equatorial and tropical regions) to higher latitudes, and by air pollution, ozone, clothing, indoor living and working habits, and sun protection. ${ }^{38,177}$ Other factors contributing to a lower vitamin $\mathrm{D}$ status in humans include certain medications, diseases, and conditions (such as obesity, liver and kidney disease, and conditions that affect fat absorption), ${ }^{177}$ and perhaps also modern dietary habits, such as a high intake of cereal grains. Epidemiological studies of populations consuming high levels of unleavened whole grain breads show rickets and vitamin $\mathrm{D}$ deficiency to be widespread, and high cereal diets can induce vitamin D deficiency in animals, including primates. ${ }^{154}$ Moreover, as pointed out by Cordain, ${ }^{154}$ a study of radiolabelled 25-hydroxyvitamin D3 (25[OH]D3) in humans consuming $60 \mathrm{~g}$ of wheat bran on a daily basis for 30 days showed an increased fecal elimination of $25(\mathrm{OH}) \mathrm{D} 3$, which may progressively reduce plasma $25[\mathrm{OH}] \mathrm{D} 3$ concentrations in humans.

Reduced plasma 25[OH]D concentrations may have serious health consequences. Indeed, there is an impressive body of evidence associating low vitamin $\mathrm{D}$ status (measured by plasma $25[\mathrm{OH}] \mathrm{D}$ ) with an increased incidence of various types of cancer (including breast, prostate, and colon), autoimmune diseases, infectious diseases, muscle weakness, osteoporosis, hypertension, insulin resistance, cardiovascular, and all-cause mortality. ${ }^{151,177-179}$

It should be mentioned that, except for fatty ocean fish, there is very little vitamin D in commonly consumed natural (ie, not artificially fortified) foods. ${ }^{177}$ As such, sensible sun exposure (adjusted to skin type, climate, time of year, and geographic region) and/or supplementation with vitamin $\mathrm{D}$ may often be pertinent in order to maintain serum 25[OH]D above $30 \mathrm{ng} / \mathrm{mL}^{177}$ (or preferably above $45 \mathrm{ng} / \mathrm{mL}) .{ }^{179}$

Another important lifestyle change is physical inactivity, which Booth et al ${ }^{146}$ call "an ancient enemy". They make a compelling case for its possible causal role in insulin resistance, dyslipidemia, obesity, hypertension, type 2 diabetes, coronary artery disease, angina, myocardial infarction, congestive heart failure, stroke, intermittent claudication, gallstones, various types of cancer, age-related cognitive dysfunction, sarcopenia, and osteopenia, among other diseases.

Regarding dietary changes, it should be mentioned that, in the US, dairy products, cereal grains (especially the refined form), refined sugars, refined vegetable oils, and alcohol make up to $70 \%$ of the total daily energy consumed. ${ }^{65}$ As pointed out by Cordain et al, ${ }^{65}$ these types of foods would have contributed little or none of the energy in the typical preagricultural hominin diet. These modern foods introduced during the Neolithic, Industrial, and Modern eras have adversely affected the following nutritional characteristics.

\section{Micronutrient density}

Calorie per calorie, fish, shellfish, meat, vegetables, and fruit present a higher micronutrient density than does milk (with the exception of calcium) and whole cereal grains (and several orders of magnitude higher than refined grains). ${ }^{65}$ Moreover, vegetable oils and refined sugars represent more than $36 \%$ of the energy in a typical US diet and are essentially devoid of micronutrients (except for vitamin $\mathrm{E}$ in some vegetable oils). ${ }^{65}$

Therefore, current food choices, ${ }^{65,154,180,181}$ together with soil depletion ${ }^{182-186}$ and modern food transport and 
stocking, ${ }^{187-189}$ are perhaps the main reasons why a significant percentage of the North American population does not reach the recommended daily allowance (RDA) of various vitamins and minerals. ${ }^{190,191}$ This problem is exacerbated by culinary methods, ${ }^{192-197}$ smoking (which causes vitamin C depletion ${ }^{198}$ ), and the use of certain foods as staples. For instance, using cereal grains as staple foods may compromise the status of various nutrients, such as vitamin B6 (because of low bioavailability ${ }^{154}$ ), biotin (perhaps because of antinutrients eliciting a depression of biotin metabolism ${ }^{154}$ ), magnesium, calcium, iron, and zinc (because their phytate content reduces intestinal absorption of these minerals ${ }^{154,180}$ ).

Even moderate micronutrient deficiency leads to a wide spectrum of pathophysiological events, and it is an important risk factor for several chronic degenerative diseases. ${ }^{65,199-206}$ For instance, data from the National Health and Nutrition Examination Survey 2001-2002 show that magnesium intake for more than $50 \%$ of US adults was below the estimated average requirement. ${ }^{190}$ Multiple epidemiologic studies associate magnesium deficiency with an increased risk of metabolic syndrome ${ }^{201,202}$ and CVD, ${ }^{203-205}$ and this causal relationship is supported by intervention studies. ${ }^{206-209}$

Other nutrients whose status is compromised in a typical western diet are zinc, folate, and vitamins C, E, and K, ${ }^{190,199,200}$ the latter (especially the K2 form) gaining widespread acceptance as a possible player in CVD. Epidemiological studies associate higher vitamin $\mathrm{K} 2$ intake with a reduced $\mathrm{CHD}$ and coronary calcification incidence. ${ }^{210-212}$

Folic acid deficiency (which would not constitute a problem in hunter-gatherer diets that included green leafy vegetables and organ meats ${ }^{65}$ ) is also a case for concern in terms of CVD prevention, as it leads to an increase in plasma homocysteine, which, although no consensus has been reached, appears to be a CVD risk factor because it induces damage of the endothelial cell wall and abnormal arterial lipid deposition, reduces vasorelaxation, and impairs fibrinolytic action. ${ }^{213}$ Perhaps more important, folate, along with vitamin B6 and B12, choline, betaine, and methionine deficiency in utero, may result in an altered epigenetic programming, ${ }^{62}$ which ultimately leads to endothelial dysfunction, ${ }^{214}$ among other pathophysiological consequences. ${ }^{62,213}$

\section{Sodium/potassium ratio}

The average potassium content $(2620 \mathrm{mg} / \mathrm{d})$ of the typical US diet is substantially lower than its sodium content ( $3271 \mathrm{mg} / \mathrm{d})$, which is due to the use of table salt, a high intake of processed foods (with added salt), and the displacement of potassium-rich foods (eg, fruit and vegetables) by potassium-poor foods, such as vegetable oils, refined sugars, whole grains, and dairy products. ${ }^{65}$

This inversion of potassium and sodium concentrations is a recent event in human evolutionary history. ${ }^{63-65,215}$ It is believed to contribute to hypertension, stroke, kidney stones, osteoporosis, gastrointestinal tract cancers, asthma, exerciseinduced asthma, insomnia, air sickness, high-altitude sickness, and Meniere's syndrome. ${ }^{65}$

\section{Net acid load}

After digestion, absorption, and metabolism, nearly all foods release either acid or base into the systemic circulation. Dairy products (especially hard cheeses), cereal grains, salt (because of the chloride ion), meats, fish, shellfish, and eggs are net acid yielding, whereas fresh fruit, vegetables, tubers, roots, and nuts are net base yielding. ${ }^{65,215}$

It was recently estimated that the diet of East African Homo sapiens during the Paleolithic era was predominantly net base producing, ${ }^{216}$ as opposed to the typical western diet, which is net acid yielding ${ }^{65,215}$ and hence leads to a chronic, low-grade metabolic acidosis, which elicits loss of calcium ions caused by mobilization of alkaline salts from bone to titrate some of the retained hydrogen ions. ${ }^{215}$ This calcium is lost in the urine without a compensatory increase in gastrointestinal absorption. ${ }^{215}$ Chronic, low-grade metabolic acidosis also induces the release of amino acids, including glutamine and amino acids that the liver can convert to glutamine. ${ }^{215}$ Glutamine is the major nitrogen source used by the kidney for synthesis of ammonia, thereby increasing the excretion of acid (as ammonium ion) in the urine and mitigating the severity of the acidosis. ${ }^{215}$ Accordingly, in the long term, a net acid-yielding diet may increase the risk for osteoporosis and sarcopenia. ${ }^{65,215}$

Furthermore, a net acid-yielding diet increases not only calcium excretion ${ }^{217}$ but also magnesium excretion. ${ }^{218}$ Finally, there is evidence that chloride (a key determinant of the diet's net acid load ${ }^{219}$ ) may be a major cause of salt-induced hypertension. ${ }^{215}$

On a final note, this chronic, low-grade metabolic acidosis is exacerbated in elderly people who experience a decline in glomerular filtration rate and hence have a decreased renal acid excretion capacity, ${ }^{65}$ which is why correcting diet-induced chronic metabolic acidosis in this age group is even more important. Hence, we propose as a solution to this chronic, low-grade metabolic acidosis a decreased intake of sodium chloride and an increased consumption of unprocessed fruit and vegetables, at the expense of refined vegetable oils, refined sugars, cereal grains, hard cheeses, and processed foods. 


\section{Antinutrient content and inflammatory potential}

Alterations in gut microbiotica ${ }^{220}$ and increased intestinal permeability ${ }^{221}$ are possible causes of low-grade chronic inflammation. Indeed, when the intestinal barrier is disrupted, it allows increased passage of gut luminal antigens derived from food, bacteria, and viruses ${ }^{221}$ into peripheral circulation (endotoxemia ${ }^{222}$ ). One particular antigen, lipopolysaccharide (LPS), from Gram-negative bacteria, is routinely used in animal experiments to induce acute immune stimulation. ${ }^{223}$ When LPS binds Toll-like receptor (TLR)4, it triggers the release of nuclear factor kappa-B (NF-kb) dimers that translocate into the cell nucleus, where they bind to DNA target sites, thereby inducing the expression of genes that code for various inflammatory enzymes, cytokines and chemokines, cell adhesion molecules, antiapoptotic and angiogenesis proteins, inducible nitric oxide synthase, and matrix-degrading enzymes ${ }^{224}$ that are involved in the atherosclerosis process. ${ }^{19,166,222,224}$ Moreover, these proinflammatory cytokines may disrupt insulin signaling, promoting insulin resistance. ${ }^{164}$ So a chronic low-grade endotoxemia may lead to low-grade chronic inflammation, ${ }^{222}$ which is at the root of various disorders. ${ }^{160,165-167,222,224,225}$

In this regard, recent evidence shows that certain western foods (dairy cream, butter, egg muffins, sausage muffins, hash browns, and sugar) allow increased passage of luminal antigens into peripheral circulation, leading to TLR2 and TLR4 activation. ${ }^{222,226-228}$ Interestingly, one study found that these events were prevented by a high intake of orange juice (perhaps because it contains flavonoids with reactive oxygen species [ROS] and inflammation-suppressive activities, such as naringenin and hesperidin), ${ }^{228}$ which opens the possibility that other fruit and vegetables may elicit similar effects.

Some factors contributing to increased intestinal permeability include nonsteroidal anti-inflammatory drugs, ${ }^{221}$ antacids, ${ }^{221}$ changes in gut microbiota, ${ }^{221}$ alcohol, ${ }^{229}$ lectins, ${ }^{221}$ saponins, ${ }^{230-235}$ and gliadin. ${ }^{236}$

It was recently found that gliadin, a prolamine in wheat (which is a novel food in the human diet in evolutionary terms ${ }^{65}$ ), increases gut permeability by means of zonulin production in the gut enterocytes. ${ }^{236}$ Zonulin causes disruption of the tight junction proteins that maintain the gut barrier function and leads to increased gut permeability. ${ }^{237}$ In addition, gliadin (which is resistant to heat and digestive enzymes $^{154}$ ) is able to interact with gut-associated lymphoid tissue, stimulating the innate immune system in celiac and nonceliac individuals (whereas the adaptive immune response is exclusive of celiac patients). ${ }^{238,239}$ Gliadin may increase intestinal permeability and hence induce the production of proinflammatory cytokines, independent of one's genetic predisposition to celiac disease (although, as expected, these effects are more marked in celiac disease). ${ }^{236,238-240}$ As such, we can deduce that chronic consumption of wheat, as happens in western countries, may lead to low-grade chronic inflammation. Of relevance, wheat gluten has been implicated in multiple sclerosis, ${ }^{154,241,242}$ type 1 diabetes, ${ }^{154,243}$ psoriasis, ${ }^{244}$ immunoglobulin (Ig)A nephropathy, ${ }^{154}$ and rheumatoid arthritis (RA). ${ }^{154,221}$ Moreover, rectal mucosal inflammatory response after gluten challenge has been observed in patients with Sjögren's syndrome. ${ }^{245}$ Furthermore, a gluten-free vegan diet over 1 year significantly reduced disease activity and oxidized low-density lipoprotein colesterol (LDL-C) in RA patients while raising natural atheroprotective antibodies against phosphorylcholine (anti-PC IgM) ${ }^{246}$ This may be relevant, as anti-PC IgM is negatively associated with atherosclerosis development in hypertensive individuals, ${ }^{247}$ and low levels of anti-PC IgM independently predict development of CVD. ${ }^{247}$ Interestingly, compared with in healthy Swedes, anti-PC IgM has been found to be significantly higher in the horticulturalists of Kitava, ${ }^{248}$ who, at the time of measurement, followed a diet composed of fish, coconut, fruit, and tubers (and hence devoid of cereal grains, dairy products, separated fats, and sugars) ${ }^{248}$ and were virtually free of autoimmune diseases, osteoporosis, obesity, insulin resistance and type 2 diabetes, CVD, and acne. ${ }^{26,74,82,112,119}$

Similar to gliadin, many plant lectins are also a recent introduction to the human diet. ${ }^{154}$ Lectins are omnipresent proteins found in the plant kingdom and likely evolved as toxic defensive mechanisms to ward off predators. ${ }^{100}$ Most of these glycoproteins are believed to be benign and nontoxic to humans, but the ones that can bind gut tissue may be problematic, such as those found in cereal grains, legumes, and certain solanaceous plants (tomatoes and potatoes). ${ }^{154,221,249}$ Most plant lectins are relatively resistant to heat ${ }^{154}$ (unless cooked by pressure cooking ${ }^{250}$ ) and digestive enzymes ${ }^{154,221}$ and have been found intact in the gastrointestinal tracts of both animals and humans. ${ }^{154,221}$ Furthermore, in animal models, lectins from legumes and cereal grains disrupt intestinal barrier and immunological function when they bind surface glycans on gut epithelial cells, causing cellular disruption and increasing gut permeability. ${ }^{221}$ They may also facilitate the growth of Gram-negative bacteria strains, ${ }^{221}$ which could, in theory, contribute to endotoxemia ${ }^{221}$ and hence low-grade inflammation through TLR4 activation by LPS.222 Perhaps even more importantly, wheat germ agglutinin (WGA) (a lectin in wheat) and phytohemagglutinin (PHA) (a lectin 
found in beans) are rapidly transported across the gut wall into systemic circulation of animals, ${ }^{221}$ and tomato and peanut lectins have been found in systemic circulation in humans following consumption of tomato juice and roasted peanuts, respectively. ${ }^{249,251}$

These findings might be important, as virtually every cell in the body and every extracellular substance can be bound by lectins because of their ability to bind glycosylated structures. ${ }^{154}$ Of note, in vitro data have shown that WGA can bind insulin and leptin receptors, ${ }^{154,252}$ which could theoretically elicit insulin and leptin resistance. ${ }^{26,100,154}$ Moreover, lectins from lentils, kidney beans, peas, and wheat potently increase the production of inflammatory cytokines (interleukin [IL]-12, IL-2, and interferon $\gamma$ ) in cell cultures, ${ }^{253}$ and WGA also stimulates production of tumor necrosis factor (TNF)- $\alpha$ and IL- $1 \beta$ in vitro. ${ }^{254}$ Furthermore, WGA and PHA induce the production of metalloproteinases (MMPs) in leukocytes, ${ }^{255,256}$ and WGA directly causes the activation of platelets and potently increases their aggregation. ${ }^{257}$ This may be relevant because rupture of the fibrous cap and formation of the blood clot, which is mediated by MMPs and platelets, is a crucial mechanism involved in thrombus production. In this regard and although these chain of events have not to our knowledge been examined in vivo, it should be mentioned that peanut oil has unexpectedly been shown to be highly atherogenic in rats, rabbits, and primates, ${ }^{258}$ and reduction of its lectin content decreases its atherogenicity. ${ }^{258}$ Interestingly, one of the very few human-controlled dietary intervention trials with hard endpoints, DART (Diet And Reinfarction Trial), found a tendency toward increased cardiovascular mortality in the group advised to eat more fiber, the majority of which was derived from cereal grains. ${ }^{259}$ Of relevance is that this nonsignificant effect became statistically significant after adjustment for possible confounding factors (such as medication and health state). ${ }^{260}$

Another class of antinutrients that may increase intestinal permeability in humans and hence endotoxemia are saponins, which are present in some cereal grains, legumes, quillaja, alfalfa sprouts, and solanaceous plants such as potatoes and green tomatoes. ${ }^{230-235}$ These steroid glycosides or triterpenoids are formed by a sugar compound (glucuronic acid, glucose, or galactose, among others) and an aglycone (nonsugar molecule) portion. ${ }^{230,231}$ By binding the cholesterol molecule on gut cell membranes, the aglycone portion disrupts the gut barrier and increases intestinal permeability. ${ }^{231}$

Unfortunately, the effects of lectins and saponins on intestinal permeability, endotoxemia, and inflammation have been poorly studied in humans to allow us to draw significant conclusions.

Novel food processing procedures, such as extreme heating, irradiation, ionization, pasteurization, and sterilization, may also promote low-grade chronic inflammation by leading to the nonenzymatic glycation and oxidation of proteins and lipids in common consumed foods. ${ }^{261}$ This complex and heterogeneous group of compounds, called advanced glycation end products (AGEs) and advanced lipid oxidation end products (ALEs), once partially absorbed into the systemic circulation may have deleterious health effects ${ }^{261}$ by direct modification of proteins and lipids ${ }^{262,263}$ (such as LDL glycation and oxidation, for instance) and perhaps also indirectly via the receptor for AGEs (RAGE). ${ }^{261,262}$ Of relevance to chronic degenerative diseases is the possible interaction of AGEs and ALEs with RAGE, which may activate several intracellular signal transduction pathways that lead to various downstream events, such as the activation of NF-kb and activator protein-1 transcription factors, ${ }^{261,262}$ which increases the expression of endothelin-1, angiotensin II, adhesion molecules, inflammatory cytokines, and plasmin activator inhibitor-1. ${ }^{261,262}$

Indeed, in diabetic patients, a high AGE intake was associated with higher levels of $\mathrm{C}$-reactive protein (CRP), TNF- $\alpha$, and vascular cell adhesion molecule (VCAM-1). ${ }^{261}$ In contrast, low-AGE diets reduce serum AGE levels, as well as markers of inflammation and vascular dysfunction (CRP, TNF- $\alpha$, and VCAM-1) in diabetic and renal failure patients. ${ }^{261,262}$ The effects of dietary AGEs and ALEs are obviously more pronounced in diabetics (who present an enhanced formation of endogenous AGEs due to hyperglycemia) ${ }^{261}$ and kidney failure patients (who have an impairment of AGE renal excretion). ${ }^{261}$ Nevertheless, in a cross-sectional study of healthy subjects of different ages, dietary AGE intake was an independent determinant of high-sensitivity CRP and of circulating AGEs, which, in turn, were associated with endogenous lipid peroxidation and HOMA index. ${ }^{263}$

AGE and ALE content in food is greatly influenced by processing and cooking conditions, including temperature, time, and moisture. ${ }^{264}$ Consequently, the avoidance of processed foods and the use of steaming, poaching, boiling, and stewing as the main cooking methods, instead of frying, broiling, and grilling, may be a sensible way to decrease the formation of these compounds. ${ }^{261,264}$ Of interest, tobacco, by being processed in the presence of reducing sugars, represents another source of exogenous AGEs. ${ }^{262}$ Indeed, circulating AGE levels have been found to be significantly higher in smokers than in nonsmokers. ${ }^{265}$ 


\section{Glycemic load, fiber, and fructose}

During the Paleolithic period, most of the carbohydrate (CHO) sources were wild fruit, berries, vegetables (typically presenting low glycemic index $\left.[\mathrm{GI}]^{26}\right)$, and sometimes tubers, with cereal and honey intake being scarce. ${ }^{14,26,65}$

Today, most $\mathrm{CHO}$ come from processed foods such as refined sugars and refined cereal grains. ${ }^{65}$ Even whole grains possess a higher glycemic load (GL) than does most unprocessed fruit and vegetables. ${ }^{65}$ The GL takes into account both the GI and the amount of $\mathrm{CHO}$ in a given serving of a food. It is estimated that the GL of Paleolithic diets was significantly lower than the GL of western diets. ${ }^{65}$

This observation is relevant because chronic adoption of a high-GL diet may lead to hyperglycemia and hyperinsulinemia, ${ }^{266}$ which may contribute to dyslipidemia (elevated serum triglycerides, small-dense LDL-C, and reduced high-density lipoprotein [HDL]-C), ${ }^{266}$ hypertension, ${ }^{267}$ elevated plasma uric acid, ${ }^{267}$ and insulin resistance, ${ }^{266}$ the primary metabolic defect in metabolic syndrome. ${ }^{266}$ Moreover, by eliciting postprandial hyperglycemia, it may increase oxidative stress, proinflammatory cytokines, protein glycation, and procoagulant activity, thereby adversely affecting endothelial function, among other pathophysiological effects. ${ }^{26,268-270}$ Indeed, a recent meta-analysis of 37 prospective cohort studies suggests that diets with a high GI, high GL, or both may increase the risk of type 2 diabetes, heart disease, and gallbladder disease. ${ }^{270}$ Furthermore, intervention studies show that a low GL diet may be an effective strategy for overweight and obesity $^{271,272}$ and confer better glucose, insulin, lipoprotein, and inflammatory cytokine profiles in overweight and type 2 diabetes patients. ${ }^{268}$ Finally, the chronic adoption of a high GL diet may lead to a number of hormonal changes (such as elevated insulin-like growth factor-1 [IGF-1]/insulin-like growth factor binding protein-3 [IGFBP-3] ratio and increased ovarian and testicular androgen synthesis, coupled with decreased sex hormone-binding globulin hepatic synthesis) that ultimately may result in polycystic ovary syndrome, epithelial cell cancers, acne, and juvenile myopia, among other diseases. ${ }^{85,119,266,273}$

Another nutritional change is fiber intake. Most Paleolithic diets had more fiber ( $>30 \mathrm{~g} / \mathrm{d})$, generally from fruit and vegetables, ${ }^{65}$ than did the typical western diet, where most of the fiber derives from cereal grains. ${ }^{65}$ Fruit and vegetables have, on a calorie per calorie basis, two and eight times more fiber than do whole grains. ${ }^{65}$ In addition, fruit and vegetables typically contain soluble fiber, whereas much fiber in cereal grains is of the insoluble type. ${ }^{26}$
This may all be relevant because dietary fiber, in particular soluble fiber, increases satiety, ${ }^{27,275}$ reduces postprandial free fatty acids, ${ }^{275}$ and contributes to better glycemic control (perhaps through a glucagon-like peptide-1 effect). ${ }^{275}$ Furthermore, dietary fiber appears to play an important role in intestinal health, as suggested by Higginson and Oettlé276 in the 1960s. They observed that in Africa, where "a large amount of roughage is consumed", colon cancer and constipation were rare, whereas they were common diseases in western countries. This was also observed by Calder et al, ${ }^{277}$ who reported that a shift from rural to urban living and at the same time from a traditional to a westerndiet (containing a low amount of fiber) and lifestyle in Kenya was associated with diverticulitis and colon carcinoma. Today, there is an increasing recognition and understanding of the complex role that fiber plays in maintaining intestinal health that goes beyond the "traditional" increased bulk and stool frequency effect. For instance, dietary fiber fermentation in human intestine produces short-chain fatty acids, mainly acetic acid, propionic acid, and butyric acid, ${ }^{278}$ which exert several beneficial effects on the intestinal tract. For instance, butyrate and propionate, by inhibition of histone deacetylase, are able to block the generation of dendritic cells (DCs) from bone marrow stem cells, thereby inhibiting the inflammatory response mediated by DCs. ${ }^{279}$ Also, butyrate controls the assembly of epithelial cell tight junctions, leading to decreased intestinal permeability, ${ }^{280}$ which may be central to many inflammatory diseases, as explained previously. Even more relevant, butyrate reduces bacterial translocation into peripheral circulation independently of intestinal permeability, ${ }^{281}$ most likely through decreased NF-kB activation. ${ }^{281}$

Although whole grains are increasingly being recommended, in part to increase fiber intake, given its potential adverse effects already discussed, it would perhaps be prudent that most of the dietary fiber came from fruit and vegetables.

Perhaps even more important, the introduction of refined sugars and, more recently, of high fructose corn syrup (HFCS), has increased fructose intake to unprecedented high levels. ${ }^{65,135}$ Mounting evidence suggests that this dietary shift may be an important player in obesity, insulin resistance, dyslipidemia, gout, hypertension, kidney disease, and nonalcoholic fatty liver disease. ${ }^{65,135,266,282,283}$ Although fruit is a natural source of fructose, it also contains vitamin $\mathrm{C}$, which offsets some of the adverse effects of fructose, ${ }^{135}$ and various other nutrients, as well as fiber. As such, consuming unprocessed 
fruit is not equivalent to consuming pure fructose, sucrose, or HFCS.

The simple fact that fructose presents a low GI, ${ }^{266}$ but yet because of its unique metabolism ${ }^{135,266}$ may have numerous adverse effects, combined with the fact that cereal grains and isolated sugars are the primary high-GL foods in the western diet, ${ }^{65}$ suggests that the historical focus on the GI and GL is incomplete and has to account for fructose and, perhaps more important, the food source of CHO.

Another food group that was not part of Paleolithic diets but is considered a staple today is dairy. ${ }^{65}$ Milk, yoghurt, and some lactose-containing cheeses, despite having a low GL, elicit a very high insulin response. ${ }^{284-288}$ The implications of these findings are not entirely known, because the epidemiological evidence is conflicting regarding the association of milk and dairy, insulin resistance, and metabolic syndrome, ${ }^{289-294}$ but a small dietary intervention study in young boys observed an increase of $103 \%$ and $75 \%$ in fasting plasma insulin concentrations and relative insulin resistance, respectively, after 7 days on a highmilk diet. ${ }^{288}$ Furthermore, epidemiologic and intervention studies in children and adults demonstrate that cow's milk significantly increases plasma levels of IGF-1 and, perhaps more important, the IGF-1/IGFBP-3 ratio. ${ }^{295}$ Moreover, milk contains various hormones and growth factors ${ }^{296-300}$ that may have relevant implications for chronic degenerative diseases. Indeed, epidemiologic evidence suggests that milk may be implicated in acne ${ }^{273,300}$ and epithelial cell cancers, ${ }^{295}$ particularly prostate cancer. ${ }^{300}$ Most of these adverse effects are more likely to manifest in the postreproductive years and, as such, would not negatively affect the selection of ALP-associated alleles. Indeed, as indicated previously, genes that are important for early reproductive success can be selected despite potentially detrimental effects subsequent to their continued expression in later life,${ }^{301}$ which is why ALP should not be viewed as genetic protection against potential adverse effects derived from long-term dairy intake.

It should be mentioned that reactive monosaccharides such as glucose and especially galactose (from dairy) ) $^{302}$ and fructose $^{303}$ (which are much more reactive than glucose) ${ }^{302,303}$ lead to AGE production and accumulate intra- and extracellularly. ${ }^{303}$ Moreover, chronic hyperglycemia is a wellknown accelerator of endogenous AGE production. ${ }^{261}$ In this regard, the chronic consumption of a high intake of sucrose, fructose, and galactose and/or the adoption of a high GL diet may significantly contribute to the formation of AGEs.
It can therefore be concluded that an increase in diet's GL and insulinotropic potential, coupled with a higher fructose (and possibly galactose) intake and a reduction in vitamin $\mathrm{C}$ and dietary fiber consumption, may be another cause of the high incidence and prevalence in industrialized countries of epithelial cell cancers, obesity, metabolic syndrome, gout, CHD, acne, myopia, and various gastrointestinal problems, including constipation, irritable bowel syndrome, and diverticulitis.

\section{Macronutrient distribution}

The percentage of total food energy (en\%) derived from macronutrients in Paleolithic diets would typically be different from current official dietary guidelines (protein $=15$ en $\%$; CHO = 55-60 en $\%$, and dietary fat $\leq 30$ en $\%) .{ }^{65}$ Cordain et al ${ }^{155}$ estimated that the diets of historically studied hunter-gatherer populations were higher in protein (19-35 en\%), lower in CHO (22-40 en\%), and equivalent or even higher in dietary fat (28-58 en \%).

Even though the RDA for daily protein is $0.8 \mathrm{~g} / \mathrm{kg}$ of bodyweight, ${ }^{304}$ there is evidence that athletes need higher amounts (in sports medicine, protein intake of $1.4-2 \mathrm{~g} / \mathrm{kg} / \mathrm{d}$ is increasingly being recommended ${ }^{305}$ ). The elderly also need a higher protein intake to prevent or attenuate sarcopenia ${ }^{306}$ and osteopenia, ${ }^{307-309}$ because dietary protein increases calcium absorption $^{307,308}$ and has an anabolic effect on muscle $e^{305,306}$ and bone cells $\mathrm{s}^{309,310}$ (especially in the context of a net base-yielding $\left.\operatorname{diet}^{310}\right)$. Moreover, high-protein diets ( $>20 \%$ of caloric intake $^{65}$ ) have been shown to improve dyslipidemia ${ }^{65,108,109}$ and insulin sensitivity ${ }^{65,81,108}$ and are potential effective strategies for improving obesity, ${ }^{65,271,311}$ metabolic syndrome, ${ }^{65}$ and hypertension. ${ }^{65,312}$ Furthermore, a long-term high-protein intake does not appear to adversely affect renal function in individuals without pre-existing kidney disease. ${ }^{313-316}$ Nevertheless, there is a hepatic urea synthesis limit, which lies between $2.6 \mathrm{~g} / \mathrm{kg} / \mathrm{d}$ and $3.6 \mathrm{~g} / \mathrm{kg} / \mathrm{d} .{ }^{155}$

Regarding the lower $\mathrm{CHO}$ content of preagricultural diets, it should be mentioned that mounting evidence suggests that a reduced-CHO diet may be superior to a western-type low-fat, high-CHO diet, especially in metabolic syndrome patients, because it may lead to better improvement in insulin resistance, postprandial lipemia, serum triglycerides, HDL-C, total cholesterol/HDL-C (TC/HDL-C) ratio, LDL particle distribution, apolipoprotein (apo)B/apo A-1 ratio, postprandial vascular function, and certain inflammatory biomarkers (such as TNF- $\alpha$, IL-6, IL-8, MCP-1, E-selectin, ICAM, and PAI-1). ${ }^{317,318}$ Nevertheless, because a low-CHO 
diet is obviously lower in sugars (such as sucrose and fructose) and cereal grains and is often higher in protein, it is unlikely that all of its positive effects can be attributed solely to $\mathrm{CHO}$ restriction.

The concern that adopting a preagriculture-type diet may encourage a higher intake of dietary fat with a consequent increase in CVD risk is not justifiable, because the absolute amount of dietary fat consumed is probably much less important than is the type of fat consumed..$^{24,108,319}$ For instance, the traditional diet of Crete, which served as a guiding template for the "Mediterranean Diet" used in clinical trials, had 35-40 en $\%$ from fat (especially cis monounsaturated fatty acids [cis MUFA] from olive oil and cis polyunsaturated fatty acids [cis PUFA] of the omega-3 family, supplied by fish, egg yolk, and wild plants such as purslane). ${ }^{319}$ The death rates from cancer and heart disease in this region of Greece were one-third the corresponding death rates in the US. ${ }^{319}$

Indeed, Mediterranean populations consuming diets rich in cis MUFA from virgin olive oil have lower CHD rates, ${ }^{319}$ and in a recent reconstructed East African Paleolithic diet, ${ }^{157}$ MUFA represented 6-19 en\%. Furthermore, various observational studies have reported an inverse association between cis MUFA and CHD risk. ${ }^{24}$ Moreover, cis MUFA intake is associated with improved lipoprotein parameters, reduced LDL oxidation, improved insulin sensitivity, and reduced thrombogenesis, ${ }^{24}$ and when it replaces $\mathrm{CHO}$ it decreases triglycerides and total cholesterol/HDL-C ratio. ${ }^{320}$

A possible and widely available food source of cis MUFA (which in evolutionary terms is a novel but yet apparently beneficial food) is virgin olive oil ${ }^{321,322}$ that also contains vitamin $\mathrm{E}$ (especially $\alpha$-, $\beta$-, and $\gamma$-tocopherol) and phenolic compounds, which may reduce LDL and DNA oxidation and increase plasma antioxidant capacity, resulting in less vascular damage by ROS. ${ }^{321,322}$ Furthermore, it may decrease the activation of NF-kB, inhibit endothelial adhesion molecule expression and platelet aggregation, and increase nitric oxide availability. ${ }^{321,322}$

In the reconstructed East African Paleolithic diet ${ }^{157}$ mentioned previously, the intake of saturated fatty acids (SAFA) was estimated at 11-12 en $\%$, and Cordain ${ }^{156}$ approximated that in historically studied hunter-gatherer populations around the globe, SAFA comprised 10-15 en\%. Although this is higher than the recommended intake $(\leq 10 \%),{ }^{65}$ it should be mentioned that even a $10 \mathrm{en} \%$ increase in SAFA intake replacing complex $\mathrm{CHO}$ is estimated to raise total and LDL-C by only $20 \mathrm{mg} / \mathrm{dL}$ and $15 \mathrm{mg} / \mathrm{dL}$ (0.005 $\mathrm{mmol} / \mathrm{L}$ and $0.004 \mathrm{mmol} / \mathrm{L})$, respectively. ${ }^{323}$ In addition, replacement of SAFA by refined $\mathrm{CHO}$ and sugars increases triglyceride levels and small LDL particles and reduces HDL-C. ${ }^{320,324}$ Moreover, not all SAFA behave in the same manner. For instance, lauric acid has a more favourable effect on TC/HDL-C than does CHO and any other fatty acid, either saturated or unsaturated, ${ }^{320}$ whereas myristic and palmitic acids appear to have little effect on this CHD risk factor. ${ }^{320}$ Furthermore, a recent meta-analysis does not support the notion that SAFA increase the risk of CHD, stroke, or CVD, ${ }^{325}$ and replacement of SAFA with high GI $\mathrm{CHO}$ has actually been found to significantly increase the risk of myocardial infarction in a recent prospective cohort study including 53,664 women and men. ${ }^{326}$ Also, there are populations, such as the horticulturalists of Kitava and the natives of Tokelau (Pacific Island), with very high SAFA intake from coconut (up to $45 \%$ of total energy in the case of Tokelau ${ }^{327}$ ) and apparently low CHD rates. ${ }^{68,112,327}$

Finally, SAFA, when consumed in the context of a higherprotein, reduced-CHO diet, are not metabolically equivalent to SAFA in the context of the typical western diet or even in the context of a prudent low-fat, high-CHO diet. Indeed, a recent trial observed that a reduced-CHO diet led to a significant decrease in circulating SAFA in triacylglycerols and cholesteryl ester, compared to a low-fat, high-CHO diet containing 3 times less dietary SAFA. ${ }^{328}$

In light of that information, we propose increasing the intake of protein (in the form of fish, shellfish, meat from grass-fed and game animals, and eggs from free-range hens) and cis MUFA (through virgin olive oil, avocados, and nuts), decreasing $\mathrm{CHO}$ consumption (especially separated sugars and cereal grains), and maintaining a moderate intake of SAFA. We also support an elimination of industrial trans fatty acids (TFA), which have no precedent in human history and are a recognized CHD risk factor, ${ }^{24,65}$ and perhaps replacing myristic and palmitic acids with lauric acid. This can be achieved through avoidance of fatty domesticated meats and dairy products and moderate consumption of virgin coconut oil, which presents antimicrobial properties, ${ }^{157}$ may promote a more pronounced reduction in abdominal obesity in the context of a hypocaloric diet, ${ }^{329}$ and may also decrease TC/HDL-C, ${ }^{320}$ LDL oxidation, ${ }^{330}$ and lipoprotein(a). ${ }^{331}$

\section{Omega-6/omega-3 ratio}

Kuipers et al ${ }^{157}$ estimated a total cis PUFA intake between 8.6 en $\%$ and 15.2 en $\%$ in East African Paleolithic diets. But more important is the balance between omega- 6 and omega-3 cis PUFA. In this regard, the ancestral dietary intake of alphalinolenic acid (ALA) and linoleic acid (LA) constituted 3.7-4.7 en \% and 2.3-3.6 en\%, respectively, ${ }^{157}$ whereas, in the US, ${ }^{24}$ ALA represents only 0.6 en $\%$ and LA 6-7 en $\%$, 
with similar intake having been reported in various western countries, leading to an unprecedent increase in the LA/ ALA ratio of the western $\operatorname{diet}^{13,65}$ to $>10 / 1$, mainly due to widespread use of LA-rich vegetable oils. ${ }^{14,24,26,65,157}$

This practice may have important implications, because a high LA/ALA ratio is found in countries with a high CHD incidence, ${ }^{332,333}$ and a high LA intake reduces the omega-3 index ${ }^{334}$ (defined as the percentage of eicosapentaenoic acid [EPA] + docosahexaenoic acid [DHA] in red blood cell membranes, relative to all other fatty acids), which has been proposed as a new CHD risk factor. ${ }^{335}$ Moreover, as reviewed by Calder, ${ }^{336}$ in vitro data from human endothelial cell studies demonstrate that LA activates NF-kB, leading to a subsequent production of proinflammatory cytokines such as IL-6 and TNF- $\alpha$.

More important, the long-held notion that replacing SAFA with LA will reduce CHD risk has recently been challenged. ${ }^{337}$ As reviewed by Ramsden et al, ${ }^{337}$ only when SAFA and TFA were replaced by a combination of omega- 6 and omega-3 cis PUFA was there a reduced risk of CHD in randomized controlled trials. In fact, LA-specific diets actually produced nonsignificant trends toward increased risks of all CHD endpoints in randomized controlled trials, with the increased risk of death from any cause approaching statistical significance. ${ }^{337}$ This data, coupled with a long-term multiple intervention trial with a diet of reduced omega- 6 fatty acids and increased omega-3 fatty acids, which showed a 70\% reduction in $\mathrm{CHD}$ events and mortality, ${ }^{338}$ strongly suggest that a high LA intake is not necessary to decrease CHD risk and may possibly increase it.

As for long-chain PUFA, Kuipers et al ${ }^{157}$ estimated that the intake of omega-3 fatty acids (EPA + DHA) and omega- 6 arachidonic acid (AA) in East African Paleolithic diets was $1.7-14.2 \mathrm{~g} / \mathrm{d}$ and $1.81-5.46 \mathrm{~g} / \mathrm{d}$, respectively. This figure contrasts with an EPA + DHA and AA mean intake of $0.11 \mathrm{~g} / \mathrm{d}$ and $0.2 \mathrm{~g} / \mathrm{d}$, respectively, in the western $\operatorname{diet}^{24,157}$

If the omega-3 index becomes accepted as a CHD risk factor, then a reduced intake of omega-3 fatty acids $(\mathrm{EPA}+\mathrm{DHA})$ in the western diet is cause for serious concern. This observation is further supported by data showing that increased consumption of omega- 3 fatty acids reduces the risk of cardiovascular mortality in both epidemiological and intervention studies. ${ }^{24,65}$ Many of these effects may derive from the fact that these fatty acids reduce ventricular arrhythmias ${ }^{24}$ and are naturally ligands for peroxisome proliferator-activated receptors (PPAR), sterol regulatory element-binding proteins (SREBP), and carbohydrate responsive element-binding protein (ChREBP). ${ }^{339}$ Hence, these fatty acids modulate gene expression involved in lipid metabolism, lipogenesis, fatty acid oxidation, cholesterol metabolism, adipokine secretion, glucose metabolism, insulin sensitivity, and inflammation. ${ }^{339}$ Furthermore, they directly downregulate the transcription factor NF-kB, which has a major role in the induction of proinflammatory genes. ${ }^{339}$

On a final note, it should be mentioned that although a Paleolithic-type diet would lead to a higher intake of AA and AA-derived eicosanoids, which initiate inflammation, AA also produces lipoxins that, together with resolvins from EPA and DHA and protectins and maresins from DHA, are involved in the resolution phase of inflammation. ${ }^{339,340}$ Accordingly, increasing the consumption of omega-3 fatty acids (EPA + DHA) from fatty fish and/or omega-3 supplements, choosing eggs and meats from grass-fed animals (which have a lower omega-6/omega-3 ratio than do grain-fed animal meat and eggs ${ }^{108,319}$ ), and decreasing the consumption of LA-rich vegetable oils may be an effective strategy to reduce the risk of various chronic inflammatory diseases.

\section{Conclusion}

The adoption of diet and lifestyle that are very different from what shaped the human genome for more than 2 million years is a major factor in the widespread prevalence of chronic degenerative diseases that are epidemic in western countries. This conclusion strongly suggests that focusing on isolated dietary or lifestyle variables is not an appropriate preventive medicine strategy.

Indeed, the evolutionary template predicts that optimal gene expression, and ultimately an increase in health span (the number of years in good health), even if it would not affect average life expectancy, will not be achieved by any single dietary or lifestyle change but rather through the combination of several measures, such as regular physical exercise; stress management; sun exposure according to latitude and skin color (in order to maintain plasma $25[\mathrm{OH}]$ D above $45 \mathrm{ng} / \mathrm{mL}$ and at the same time avoiding the adverse effects of excessive sun exposure); adequate sleep; avoidance of tobacco smoke; reduced exposure to pollutants, dietary AGEs, ALES, and other Maillard reaction compounds; and the adoption of a diet similar to that followed by Paleolithic hunter-gatherers. Giving support to this notion, four recent human intervention trials ${ }^{18,23,341,342}$ and one animal trial ${ }^{143}$ have demonstrated that a diet composed of meat, fish, shellfish, eggs, fresh fruit and vegetables, roots, tubers, nuts, and seeds may be superior to so-called healthy diets such as the Mediterranean diet. ${ }^{341}$ 


\section{Acknowledgments}

We thank Mr Ricardo Reis Carvalho and Drs Christopher Ramsden and Stephan Guyenet for their critical contributions to this manuscript. We also express our gratitude to Professor Frits Muskiet for his enlightening comments regarding evolutionary medicine and the biochemistry of fatty acids.

\section{Disclosure}

The authors report no conflicts of interest in this work.

\section{References}

1. Eaton SB, Konner M. Paleolithic nutrition. A consideration of its nature and current implications. N Engl J Med. 1985;312(5):283-289.

2. Shatin R. The transition from food-gathering to food production in evolution and disease. Vitalstoffe Zivilisationskrankheiten. 1967;12: 104-107.

3. Abrams HL. The relevance of Paleolithic diet in determining contemporary nutritional needs. J Appl Nutr. 1979;31:43-59.

4. Nesse RM, Williams GC. Why we Get Sick. The New Science of Darwinian Medicine. New York: Times Books; 1994.

5. Broadhurst CL. Balanced intakes of natural triglycerides for optimum nutrition: an evolutionary and phytochemical perspective. Med Hypotheses. 1997;49(3):247-261.

6. Mann N. Dietary lean red meat and human evolution. Eur J Nutr. 2000; 39(2):71-79.

7. Boaz N. Evolving Health: The Origins of Illness and How the Modern World is Making us Sick. New York: John Wiley \& Sons; 2002.

8. Chakravarthy MV, Booth FW. Eating, exercise, and "thrifty" genotypes: connecting the dots toward an evolutionary understanding of modern chronic diseases. J Appl Physiol. 2004;96(1):3-10.

9. Halberg N, Henriksen M, Soderhamn N, et al. Effect of intermittent fasting and refeeding on insulin action in healthy men. J Appl Physiol. 2005;99(6):2128-2136.

10. Gluckman P, Hanson M. Mismatch: Why Our World No Longer Fits Our Bodies. Oxford: Oxford University Press; 2006.

11. De Graaf C. Effects of snacks on energy intake: an evolutionary perspective. Appetite. 2006;47(1):18-23.

12. Halperin ML, Cheema-Dhadli S, Lin SH, Kamel KS. Control of potassium excretion: a Paleolithic perspective. Curr Opin Nephrol Hypertens. 2006;15(4):430-436.

13. Simopoulos AP. Evolutionary aspects of diet, the omega-6/omega-3 ratio and genetic variation: nutritional implications for chronic diseases. Biomed Pharmacother. 2006;60(9):502-507.

14. Cordain L. Implications of Plio-Pleistocene hominin diets for modern humans. In: Ungar P, editor. Evolution of the Human Diet: The Known, the Unknown, and the Unknowable. New York: Oxford University Press; 2007:363-383.

15. Turner BL, Maes K, Sweeney J, Armelagos GJ. Human evolution, diet, and nutrition. In: Trevathan WR, Smith EO, McKenna JJ, editors. Evolutionary Medicine and Health: New Perspectives. Oxford: Oxford University Press; 2008:55-71.

16. Leonard WR. Lifestyle, diet, and disease: comparative perspectives on the determinants of chronic health risks. In: Stearns SC, Koella JC, editors. Evolution in Health and Disease. 2nd ed. New York: Oxford University Press; 2008:265-276.

17. Hood E, Jenkins KP. Evolutionary medicine: a powerful tool for improving human health. Evo Edu Outreach. 2008;1:114-120.

18. Osterdahl M, Kocturk T, Koochek A, Wändell PE. Effects of a short-term intervention with a Paleolithic diet in healthy volunteers. Eur J Clin Nutr. 2008;62(5):682-685.

19. Lamon BD, Hajjar DP. Inflammation at the molecular interface of atherogenesis: an anthropological journey. Am J Pathol. 2008;173(5):1253-1264.
20. BMA Board of Science. Early Life Nutrition and Lifelong Health. London: British Medical Association; 2009.

21. Maziak W. Point-counterpoint. The triumph of the null hypothesis: epidemiology in an age of change. Int J Epidemiol. 2009;38(2):393-402.

22. Pettee KK, Ainsworth BE. The Building Healthy Lifestyles Conference: modifying lifestyles to enhance physical activity, diet, and reduce cardiovascular disease. Am J Lifestyle Med. 2009; 3(1 Suppl):6s-10s.

23. Frassetto LA, Schloetter M, Mietus-Synder M, et al. Metabolic and physiologic improvements from consuming a paleolithic, huntergatherer type diet. Eur J Clin Nutr. 2009;63(8):947-955.

24. Ramsden CE, Faurot KR, Carrera-Bastos P, et al. Dietary fat quality and coronary heart disease prevention: a unified theory based on evolutionary, historical, global, and modern perspectives. Curr Treat Options Cardiovasc Med. 200;11(4):289-301.

25. Omenn GS. Evolution in health and medicine Sackler colloquium: evolution and public health. Proc Natl Acad Sci USA. 2010;107 Suppl 1: 1702-1709.

26. Lindeberg S. Food and Western Disease: Health and Nutrition from an Evolutionary Perspective. Chichester, UK: Wiley-Blackwell; 2010.

27. Muskiet FAJ, Kuipers RS. Lessons from shore-based hunter-gatherer diets in East Africa. In: Cunnane SC, Stewart K, editors. Human Brain Evolution: The Influence of Freshwater and Marine Food Resources. New Jersey: John Wiley \& Sons; 2010:77-104.

28. Tishkoff SA, Varkonyi R, Cahinhinan N, et al. Haplotype diversity and linkage disequilibrium at human G6PD: recent origin of alleles that confer malarial resistance. Science. 2001;293(5529): 455-462.

29. Moalem S, Weinberg ED, Percy ME. Hemochromatosis and the enigma of misplaced iron: implications for infectious disease and survival. Biometals. 2004;17(2):135-139.

30. Akey JM, Eberle MA, Rieder MJ, et al. Population history and natural selection shape patterns of genetic variation in 132 genes. PLoS Biol. 2004;2(10):e286.

31. Duncan SR, Scott S, Duncan CJ. Reappraisal of the historical selective pressures for the CCR5-Delta32 mutation. J Med Genet. 2005;42(3):205-208.

32. Armelagos GJ, Harper KN. Genomics at the origin of agriculture, part one. Evol Anthropol. 2005;14:68-77.

33. Wang ET, Kodama G, Baldi P, Moyzis RK. Global landscape of recent inferred Darwinian selection for Homo sapiens. Proc Natl Acad Sci US A. 2006;103(1):135-40.

34. Voight BF, Kudaravalli S, Wen X, Pritchard JK. A map of recent positive selection in the human genome. PLoS Biol. 2006;4(3):e72.

35. Pollard KS, Salama SR, Lambert N, et al. An RNA gene expressed during cortical development evolved rapidly in humans. Nature. 2006;443(7108):167-172.

36. Hawks J, Wang ET, Cochran GM, et al. Recent acceleration of human adaptive evolution. Proc Natl Acad Sci U S A. 2007;104(52): 20753-20758.

37. Hancock AM, Witonsky DB, Gordon AS, et al. Adaptations to climate in candidate genes for common metabolic disorders. PLoS Genet. 2008;4(2):e32.

38. Chaplin G, Jablonski NG. Vitamin D and the evolution of human depigmentation. Am J Phys Anthropol. 2009;139(4):451-461.

39. Yi X, Liang Y, Huerta-Sanchez E, et al. Sequencing of 50 human exomes reveals adaptation to high altitude. Science. 2010;329(5987):75-78.

40. Richerson PJ, Boyd R, Henrich J. Colloquium paper: gene-culture coevolution in the age of genomics. Proc Natl Acad Sci U S A. 2010; 107 Suppl 2:8985-8992.

41. Hancock AM, Witonsky DB, Ehler E, et al. Colloquium paper: human adaptations to diet, subsistence, and ecoregion are due to subtle shifts in allele frequency. Proc Natl Acad Sci U S A. 2010;107 Suppl 2: 8924-8930.

42. Luca F, Perry GH, Di Rienzo A. Evolutionary adaptations to dietary changes. Annu Rev Nutr. 2010;30:291-314.

43. Pritchard JK. How we are evolving. Sci Am. 2010;303(4):40-47. 
44. Underhill PA, Shen PD, Lin AA, et al. Y chromosome sequence variation and the history of human populations. Nat Genet. 2000;26: 358-361.

45. Tishkoff S, Williams S. Genetic analysis of African populations: human evolution and complex disease. Nat Rev Genet. 2002;3:611-621.

46. Conrad D, Jakobsson M, Coop G, et al. A world-wide survey of haplotype variation and linkage disequilibrium in the human genome. Nat Genet. 2006;38:1251-1260.

47. Cavalli-Sforza LL, Feldman MW. The application of molecular genetic approaches to the study of human evolution. Nat Genet. 2003;33: 266-275.

48. White TD, Asfaw B, DeGusta D, et al. Pleistocene Homo sapiens from Middle Awash, Ethiopia. Nature. 2003;423(6941):742-747.

49. McDougall I, Brown FH, Fleagle JG. Stratigraphic placement and age of modern humans from Kibish, Ethiopia. Nature. 2005;433:733-736.

50. Ramachandran S, Deshpande O, Roseman CC, et al. Support from the relationship of genetic and geographic distance in human populations for a serial founder effect originating in Africa. Proc Natl Acad Sci US A. 2005;102(44):15942-15947.

51. Ray N, Currat M, Berthier P, Excoffier L. Recovering the geographic origin of early modern humans by realistic and spatially explicit simulations. Genome Res. 2005;15:1161-1167.

52. Liu H, Prugnolle F, Manica A, Balloux F. A geographically explicit genetic model of worldwide human-settlement history. Am J Hum Genet. 2006;79(2):230-237.

53. Manica A, Amos W, Balloux F, Hanihara T. The effect of ancient population bottlenecks on human phenotypic variation. Nature. 2007;448(7151):346-348.

54. Hudjashov G, Kivisild T, Underhill P, et al. Revealing the prehistoric settlement of Australia by $\mathrm{Y}$ chromosome and mtDNA analysis. PNAS. 2007; 104:8726-8730.

55. Hellenthal G, Auton A, Falush D. Inferring human colonization history using a copying model. PLoS Genet. 2008;4(5):e1000078.

56. Deshpande O, Batzoglou S, Feldman MW, Cavalli-Sforza LL. A serial founder effect model for human settlement out of Africa. Proc Biol Sci. 2009;276(1655):291-300.

57. Campbell MC, Tishkoff SA. The evolution of human genetic and phenotypic variation in Africa. Curr Biol. 2010;20(4):R166-R173.

58. Jakobsson M, Scholz SW, Scheet P, et al. Genotype, haplotype and copy-number variation in worldwide human populations. Nature. 2008;451(7181):998-1003.

59. Green RE, Krause J, Briggs AW, et al. A draft sequence of the Neandertal genome. Science. 2010;328(5979):710-722.

60. Ingram CJ, Mulcare CA, Itan Y, et al. Lactose digestion and the evolutionary genetics of lactase persistence. Hum Genet. 2009;124(6):579-591.

61. Eaton SB, Strassman BI, Nesse RM, et al. Evolutionary health promotion. Prev Med. 2002;34(2):109-118.

62. Muskiet FAJ. Adaptation to the conditions of existence. Ned Tijdschr Klin Chem Labgeneesk. 2006;31:187-193.

63. Sebastian A, Frassetto LA, Sellmeyer DE, Morris RC Jr. The evolution-informed optimal dietary potassium intake of human beings greatly exceeds current and recommended intakes. Semin Nephrol. 2006;26(6):447-453.

64. Eaton SB. The ancestral human diet: what was it and should it be a paradigm for contemporary nutrition? Proc Nutr Soc. 2006;65(1):1-6.

65. Cordain L, Eaton SB, Sebastian A, et al. Origins and evolution of the Western diet: health implications for the 21st century. Am J Clin Nutr. 2005;81(2):341-354.

66. Eaton SB, Cordain L, Lindeberg S. Evolutionary health promotion: a consideration of common counterarguments. Prev Med. 2002;34(2): 119-123.

67. Eaton SB, Konner M, Shostak M. Stone agers in the fast lane: chronic degenerative diseases in evolutionary perspective. Am J Med. 1988;84(4):739-749.

68. Lindeberg S, Nilsson-Ehle P, Terént A, et al. Cardiovascular risk factors in a Melanesian population apparently free from stroke and ischaemic heart disease: the Kitava study. J Intern Med. 1994;236:331-340.
69. Oliver WJ, Cohen EL, Neel JV. Blood pressure, sodium intake, and sodium related hormones in the Yanomamo Indians, a "no-salt" culture. Circulation. 1975;52(1):146-151.

70. National High Blood Pressure Education Program. The Seventh Report of the Joint National Committee on Prevention, Detection, Evaluation, and Treatment of High Blood Pressure. Bethesda (MD): National Heart, Lung, and Blood Institute (US); 2004.

71. Merimee TJ, Rimoin DL, Cavalli-Sforza LL. Metabolic studies in the African pygmy. J Clin Invest. 1972;51:395-401.

72. Kuroshima A, Itoh S, Azuma T, Agishi Y. Glucose tolerance test in the Ainu. Int J Biometerol. 1972;16:193-197.

73. Spielmann RS, Fajans SS, Neel JV, et al. Glucose tolerance in two unacculturated Indian tribes of Brazil. Diabetologia. 1982;23: 90-93.

74. Lindeberg S, Eliasson M, Lindahl B, Ahren B. Low serum insulin in traditional Pacific Islanders: the Kitava study. Metabolism. 1999;48:1216-1219.

75. Lindgärde F, Widén I, Gebb M, Ahrén B. Traditional versus agricultural lifestyle among Shuar women of the Ecuadorian Amazon: effects on leptin levels. Metabolism. 2004;53(10):1355-1358.

76. Pavan L, Casiglia E, Braga LM, et al. Effects of a traditional lifestyle on the cardiovascular risk profile: the Amondava population of the Brazilian Amazon. Comparison with matched African, Italian and Polish populations. J Hypertens. 1999;17(6):749-756.

77. King H, Heywood P, Zimmet P, et al. Glucose tolerance in a highland population in Papua New Guinea. Diabetes Res. 1984;1(1):45-51.

78. Martin FI, Wyatt GB, Griew AR, et al. Diabetes mellitus in urban and rural communities in Papua New Guinea. Studies of prevalence and plasma insulin. Diabetologia. 1980;18(5):369-374.

79. King H, Finch C, Collins A, et al. Glucose tolerance in Papua New Guinea: ethnic differences, association with environmental and behavioural factors and the possible emergence of glucose intolerance in a highland community. Med J Aust. 1989;151(4): 204-210.

80. O’Dea K, Spargo RM, Akerman K. The effect of transition from traditional to urban life-style on the insulin secretory response in Australian aborigines. Diabetes Care. 1980;3(1):31-37.

81. O'Dea K. Marked improvement in carbohydrate and lipid metabolism in diabetic Australian aborigines after temporary reversion to traditional lifestyle. Diabetes. 1984;33(6):596-603.

82. Lindeberg S, Soderberg S, Ahren B, Olsson T. Large differences in serum leptin levels between non-Westernized and Westernized populations: the Kitava study. J Intern Med. 2001;249:553-558.

83. Bribiescas RG, Hickey MS. Population variation and differences in serum leptin independent of adiposity: a comparison of Ache Amerindian men of Paraguay and lean American male distance runners. Nutr Metab (Lond). 2006;3:34.

84. World Health Organization (WHO). Global Database on Body Mass Index. http://www.who.int/bmi/index.jsp. Accessed October 10, 2010.

85. Cordain L, Eaton SB, Brand Miller J, et al. An evolutionary analysis of the etiology and pathogenesis of juvenile-onset myopia. Acta Ophthal Scand. 2002;80:125-135.

86. Agarwal SC, Grynpas MD. Bone quantity and quality in past populations. Anat Rec. 1996;246(4):423-432.

87. Webb S. Palaeopathology of Aboriginal Australians: Health and Disease Across a Hunter-Gatherer Continent. Cambridge: Cambridge University Press; 1995.

88. Perzigian AJ. Osteoporotic bone loss in two prehistoric Indian populations. Am J Phys Anthropol. 1973;39(1):87-95.

89. Nelson DA. Bone density in three archaeological populations. Am J Phys Anthropol. 1984;63:198.

90. Ericksen MF. Cortical bone loss with age in three Native American populations. Am J Phys Anthropol. 1976;45:443-452.

91. Abbott S, Trinkaus E, Burr DB. Dynamic bone remodeling in later Pleistocene fossil hominids. Am J Phys Anthropol. 1996;99: 585-601. 
92. Ruff CB, Trinkaus E, Walker A, Larsen CS. Postcranial robusticity in Homo. I: Temporal trends and mechanical interpretation. Am J Phys Anthropol. 1993;91(1):21-53.

93. RuffCB, Trinkaus E, Holliday TW. Body mass estimation in Olympic athletes and Pleistocene Homo. Am J Phys Anthropol. 1998;26:192-193.

94. Ruff CB. Body mass prediction from skeletal frame size in elite athletes. Am J Phys Anthropol. 2000;113:507-517.

95. Trinkaus E. Appendicular robusticity and the paleobiology of modern human emergence. Proc Natl Acad Sci U S A. 1997;94(24): 13367-13373.

96. Kanis JA, Johnell O, De Laet C, et al. International variations in hip fracture probabilities: implications for risk assessment. J Bone Miner Res. 2002;17(7):1237-1244.

97. Yoshimura N, Suzuki T, Hosoi T, Orimo H. Epidemiology of hip fracture in Japan: incidence and risk factors. J Bone Miner Metab. 2005;23 Suppl:78-80.

98. Palvanen M, Kannus P, Niemi S, Parkkari J. Secular trends in the osteoporotic fractures of the distal humerus in elderly women. Eur $J$ Epidemiol. 1998;14(2):159-164.

99. Barss P. Fractured hips in rural Melanesians: a nonepidemic. Trop Geogr Med. 1985;37(2):156-159.

100. Jönsson T, Olsson S, Ahrén B, et al. Agrarian diet and diseases of affluence: do evolutionary novel dietary lectins cause leptin resistance? BMC Endocr Disord. 2005;5:10.

101. Arthaud JB. Causes of death in 339 Alaskan Eskimos as determined by autopsy. Arch Pathol. 1970;90:433-438.

102. Bang HO, Dyerberg J. Lipid metabolism and ischemic heart disease in Greenland Eskimos. Adv Nutr Res. 1980;3:1-22.

103. Bjerregaard P, Dyerberg J. Mortality from ischemic heart disease and cerebrovascular disease in Greenland. Int J Epidemiol. 1988;17: 514-519.

104. Gottman AW. A report of one hundred and three autopsies in Alaskan natives. Arch Pathol. 1960;70:117-124.

105. Kromann N, Green A. Epidemiological studies in the Upernavik district, Greenland. Incidence of some chronic diseases 1950-1974. Acta Med Scand. 1980;208:401-406.

106. Middaugh JP. Cardiovascular deaths among Alaskan natives, 1980-86. Am J Public Health. 1990;80:282-285.

107. Young TK, Moffatt MEK, O’Neil JD. Cardiovascular diseases in an Arctic population: an epidemiological perspective. Am J Public Health. 1993;83:881-887.

108. Cordain L, Eaton SB, Brand Miller J, et al. The paradoxical nature of hunter-gatherer diets: meat based, yet non-atherogenic. Eur J Clin Nutr. 2002;56(Suppl 1):S42-S52.

109. O'Keefe JH Jr, Cordain L. Cardiovascular disease resulting from a diet and lifestyle at odds with our Paleolithic genome: how to become a 21st-century hunter-gatherer. Mayo Clin Proc. 2004;79(1): 101-108.

110. Lindeberg S, Berntorp E, Carlsson R, et al. Haemostatic variables in Pacific Islanders apparently free from stroke and ischaemic heart disease. Thromb Haemost. 1997;77:94-98.

111. Lindeberg S, Berntorp E, Nilsson-Ehle P, et al. Age relations of cardiovascular risk factors in a traditional Melanesian society: the Kitava Study. Am J Clin Nutr. 1997;66:845-852.

112. Lindeberg S, Lundh B. Apparent absence of stroke and ischaemic heart disease in a traditional Melanesian Island: a clinical study in Kitava. J Intern Med. 1993;233:269-275.

113. Eaton S, Pike M, Short R, et al. Women's reproductive cancers in evolutionary context. $Q$ Rev Biol. 1994;69:353-367.

114. Capasso LL. Antiquity of cancer. Int J Cancer. 2005;113(1): $2-13$.

115. Bulkley JL. Cancer among primitive tribes. Cancer. 1927;4(4): 289-295

116. Riveros M. First observation of cancer among the Pampido Indians of the Paraguayan Chaco. Int Surg. 1970;53(1):51-55.

117. Hearsey $\mathrm{H}$. The rarity of cancer among the aborigines of British Central Africa. Br Med J. 1906;1562-1563.
118. Dewailly E, Mulvad G, Sloth Pedersen H, et al. Inuit are protected against prostate cancer. Cancer Epidemiol Biomarkers Prev. 2003;12(9):926-927.

119. Cordain L, Lindeberg S, Hurtado M, et al. Acne vulgaris: a disease of Western civilization. Arch Dermatol. 2002;138:1584-1590.

120. Narayan KM, Boyle JP, Geiss LS, et al. Impact of recent increase in incidence on future diabetes burden: US, 2005-2050. Diabetes Care. 2006;29(9):2114-2116.

121. Ruffer M. On arterial lesions found in Egyptian mummies. J Pathol Bacteriol. 1911;15:453-462.

122. Bruetsch WL. The earliest record of sudden death possibly due to atherosclerotic coronary occlusion. Circulation. 1959;20:438-441.

123. Cockburn A, Barraco RA, Reyman TA, Peck WH. Autopsy of an Egyptian mummy. Science. 1975;187:1155-1160.

124. Pollard TM. Western Diseases: An Evolutionary Perspective. Cambridge: Cambridge University Press; 2008.

125. Schaeffer O. When the Eskimo comes to town. Nutr Today. 1971;6: 8-16.

126. O'Dea K, Patel M, Kubisch D, et al. Obesity, diabetes and hyperlipidaemia in a Central Australia Aboriginal community with a long history of acculturation. Diabetes Care. 1993;16:1004-1010.

127. Dowse GK, Spark RA, Mavo B, Hodge AM. Extraordinary prevalence of non-insulin-dependent diabetes mellitus and bimodal plasma glucose distribution in the Wanigela people of Papua New Guinea. Med J Aust. 1994;160:767-774.

128. Szathmary EJE. Non-insulin dependent diabetes mellitus among aboriginal North Americans. Annu Rev Anthropol. 1994;23:457-482.

129. Hodge AM, Dowse GK, Koki G, et al. Modernity and obesity in coastal and Highland Papua New Guinea. Int J Obes Relat Metab Disord. 1995;19(3):154-161.

130. Ebbesson SO, Schraer CD, Risica PM, et al. Diabetes and impaired glucose tolerance in three Alaskan Eskimo populations: the AlaskaSiberia Project. Diabetes Care. 1998;21:563-569.

131. Daniel M, Rowley KG, McDermott R, et al. Diabetes incidence in an Australian aboriginal population: an 8-year follow-up study. Diabetes Care. 1999;22:1993-1998.

132. Cockram CS. Diabetes mellitus: perspective from the Asia-Pacific region. Diabetes Res Clin Pract. 2000;50(Suppl 2):S3-S7.

133. Kaler SN, Ralph-Campbell K, Pohar S, et al. High rates of the metabolic syndrome in a First Nations Community in Western Canada: prevalence and determinants in adults and children. Int J Circumpolar Health. 2006;65(5):389-402.

134. Yu CH, Zinman B. Type 2 diabetes and impaired glucose tolerance in aboriginal populations: a global perspective. Diabetes Res Clin Pract. 2007;78(2):159-170.

135. Johnson RJ, Perez-Pozo SE, Sautin YY, et al. Hypothesis: could excessive fructose intake and uric acid cause type 2 diabetes? Endocr Rev. 2009;30(1):96-116.

136. Ebbesson SO, Adler AI, Risica PM, et al. Cardiovascular disease and risk factors in three Laskan Eskimo populations: the Alaska-Siberia project. Int J Circumpolar Health. 2005;64(4):365-386.

137. Renner W. The spread of cancer among the descendents of the liberated Africans or Creoles of Serra Leona. Br Med J. 1910:587-589.

138. Day G, Lanier A. Alaska native mortality, 1979-1998. Public Health Rep. 2003;118:518-530.

139. Valway S. Cancer Mortality Among Native Americans in the United States: Regional Differences in Indian Health 1984-1988 and Trends Over Time. Rockville, MD: Indian Health Service; 1992.

140. Baquet C. Native Americans' cancer rates in comparison with other peoples of color. Cancer. 1996;78:1538-1544.

141. Lanier A. Cancer incidence in Alaska natives: comparison of two time periods, 1989-93 vs 1969-73. Cancer Suppl. 1998;83:1815-1817.

142. Lanier A, Jones D. Existence of Alaska native health disparities. Am J Public Health. 2007;97(9):1541-1542.

143. Louchini R, Beaupré M. Cancer incidence and mortality among aboriginal people living on reserves and northern villages in Québec, 1988-2004. Int J Circumpolar Health. 2008;67(5):445-451. 
144. Hildes JA, Schaefer O. The changing picture of neoplastic disease in the Western and Central Canadian Arctic (1950-1980). Can Med Assoc J. 1984;130:25-32.

145. Robinson EJ, Gebre Y, Pickering JL, et al. Effect of bush living on aboriginal Canadians of the Eastern James Bay region with non-insulin-dependent diabetes mellitus. Chronic Dis Can. 1995;16: 144-148.

146. Booth FW, Chakravarthy MV, Gordon SE, Spangenburg EE. Waging war on physical inactivity: using modern molecular ammunition against an ancient enemy. J Appl Physiol. 2002;93(1):3-30.

147. Booth FW, Lees SJ. Fundamental questions about genes, inactivity, and chronic diseases. Physiol Genomics. 2007;28(2):146-157.

148. Booth FW, Laye MJ. The future: genes, physical activity and health. Acta Physiol (Oxf). 2010;199(4):549-556.

149. Gurven M, Kaplan H. Longevity among hunter-gatherers: a crosscultural examination. Popul Dev Rev. 2007;33:321-365.

150. Angel LJ. Health as a crucial factor in the changes from hunting to developed farming in the eastern Mediterranean. In: Cohen MN, Armelagos GJ, editors. Paleopathology at the Origins of Agriculture. Orlando: Academic Press; 1984:51-73.

151. Vieth R. What is the optimal vitamin D status for health? Prog Biophys Mol Biol. 2006;92(1):26-32.

152. Wiley TS, Formby B. Lights Out: Sleep, Sugar and Survival. New York: Pocket Books; 2000.

153. Cordain L, Gotshall RW, Eaton SB, Eaton SB 3rd. Physical activity, energy expenditure and fitness: an evolutionary perspective. Int $J$ Sports Med. 1998;19(5):328-335.

154. Cordain L. Cereal grains: humanity's double-edged sword. World Rev Nutr Diet. 1999;84:19-73.

155. Cordain L, Brand Miller J, Eaton SB, et al. Plant to animal subsistence ratios and macronutrient energy estimations in world wide huntergatherer diets. Am J Clin Nutr. 2000;71:682-692.

156. Cordain L. Saturated fat consumption in ancestral human diets: implications for contemporary intakes. In: Meskin MS, Bidlack WR, Randolph RK, editors. Phytochemicals, Nutrient-Gene Interactions. Boca Raton, FL: CRC Press; 2006:115-126.

157. Kuipers RS, Luxwolda MF, Janneke Dijck-Brouwer DA, et al. Estimated macronutrient and fatty acid intakes from an East African Paleolithic diet. Br J Nutr. 2010:1-22.

158. Deutch B, Dyerberg J, Pedersen HS, et al. Traditional and modern Greenlandic food: dietary composition, nutrients and contaminants. Sci Total Environ. 2007;384(1-3):106-119.

159. Kuhnlein HV, Receveur O. Local cultural animal food contributes high levels of nutrients for Arctic Canadian indigenous adults and children. J Nutr. 2007;137(4):1110-1114.

160. Rook GA. 99th Dahlem conference on infection, inflammation and chronic inflammatory disorders: Darwinian medicine and the 'hygiene' or 'old friends' hypothesis. Clin Exp Immunol. 2010;160(1):70-79.

161. Black PH. The inflammatory response is an integral part of the stress response: implications for atherosclerosis, insulin resistance, type II diabetes and metabolic syndrome X. Brain Behav Immun. 2003;17(5): 350-364.

162. Mills NL, Donaldson K, Hadoke PW, et al. Adverse cardiovascular effects of air pollution. Nat Clin Pract Cardiovasc Med. 2009;6(1):36-44.

163. Vardavas CI, Panagiotakos DB. The causal relationship between passive smoking and inflammation on the development of cardiovascular disease: a review of the evidence. Inflamm Allergy Drug Targets. 2009;8(5):328-333.

164. S Tilg H, Moschen AR. Inflammatory mechanisms in the regulation of insulin resistance. Mol Med. 2008;14(3-4):222-231.

165. Kolb H, Mandrup-Poulsen T. The global diabetes epidemic as a consequence of lifestyle-induced low-grade inflammation. Diabetologia. 2010;53(1):10-20.

166. Hanson GK. Inflammation, atherosclerosis and coronary artery disease. N Engl J Med. 2005;352:1658-1695.

167. Cashman KD. Altered bone metabolism in inflammatory disease: role for nutrition. Proc Nutr Soc. 2008;67(2):196-205.
168. Soto AM, Sonnenschein C. Environmental causes of cancer: endocrine disruptors as carcinogens. Nat Rev Endocrinol. 2010;6(7):363-370.

169. Nadal A, Alonso-Magdalena P, Soriano S, et al. The pancreatic beta-cell as a target of estrogens and xenoestrogens: implications for blood glucose homeostasis and diabetes. Mol Cell Endocrinol. 2009;304(1-2):63-68.

170. Lang IA, Galloway TS, Scarlett A, et al. Association of urinary bisphenol A concentration with medical disorders and laboratory abnormalities in adults. JAMA. 2008;300(11):1303-1310.

171. Grün F, Blumberg B. Endocrine disrupters as obesogens. Mol Cell Endocrinol. 2009;304(1-2):19-29.

172. Melzer D, Rice NE, Lewis C, et al. Association of urinary bisphenol a concentration with heart disease: evidence from NHANES 2003/06. PLoS One. 2010;5(1):e8673.

173. Vgontzas AN, Zoumakis E, Bixler EO, et al. Adverse effects of modest sleep restriction on sleepiness, performance, and inflammatory cytokines. J Clin Endocrinol Metab. 2004;89:2119-2126.

174. Tasali E, Leproult R, Spiegel K. Reduced sleep duration or quality: relationships with insulin resistance and type 2 diabetes. Prog Cardiovasc Dis. 2009;51:381-391.

175. Krueger PM, Friedman EM. Sleep duration in the United States: a cross-sectional population-based study. Am J Epidemiol. 2009;169(9): 1052-1063.

176. Haus E, Smolensky M. Biological clocks and shift work: circadian dysregulation and potential long-term effects. Cancer Causes Control. 2006 May; 17(4):489-500.

177. Holick MF. Vitamin D deficiency. $N$ Engl J Med. 2007;357(3): 266-281.

178. Lee JH, O’Keefe JH, Bell D, et al. Vitamin D deficiency an important, common, and easily treatable cardiovascular risk factor? $\mathrm{J} \mathrm{Am} \mathrm{Coll}$ Cardiol. 2008;52(24):1949-1956.

179. Grant WB. In defense of the sun: an estimate of changes in mortality rates in the United States if mean serum 25-hydroxyvitamin D levels were raised to $45 \mathrm{ng} / \mathrm{mL}$ by solar ultraviolet-B irradiance. Dermatoendocrinol. 2009;1(4):207-214.

180. Bohn T, Davidsson L, Walczyk T, Hurrell RF. Phytic acid added to white-wheat bread inhibits fractional apparent magnesium absorption in humans. Am J Clin Nutr. 2004;79(3):418-423.

181. Hallberg L, Rossander-Hultén L, Brune M, Gleerup A. Calcium and iron absorption: mechanism of action and nutritional importance. Eur J Clin Nutr. 1992;46(5):317-327.

182. Shambaugh GE Jr. Zinc: the neglected nutrient. Am J Otol. 1989;10(2):156-160.

183. Miron W, Sobaniec-Lotowska M, Sulkowski S. [Malignant neoplasms in autopsy specimens and the magnesium level in the soil of the communities of Grodek and Tykocin]. Wiad Lek. 1989;42(19-21): 1033-1037.

184. Clark LC, Cantor KP, Allaway WH. Selenium in forage crops and cancer mortality in US counties. Arch Environ Health. 1991;46(1): $37-42$.

185. Maksimovic Z, Rsumovic M, Jovic V, et al. Selenium in soil, grass, and human serum in the Zlatibor mountain area (Serbia): geomedical aspects. J Environ Pathol Toxicol Oncol. 1998;17(3-4):221-227.

186. Fan MS, Zhao FJ, Fairweather-Tait SJ, et al. Evidence of decreasing mineral density in wheat grain over the last 160 years. J Trace Elem Med Biol. 2008;22(4):315-324.

187. Sweeney JP, Marsh AC. Effect of processing on provitamin A in vegetables. J Am Diet Assoc. 1971;59(3):238-243.

188. Carlson BL, Tabacchi MH. Loss of vitamin C in vegetables during the food service cycle. J Am Diet Assoc. 1988;88:65-67.

189. Kmiecik W, Lisiewska Z. Effect of the variety and size of fresh and frozen brussels sprouts on the vitamin C level. Rocz Panstw Zakl Hig. 1989;40(3):215-222.

190. Moshfegh A, Goldman J, Cleveland L. What We Eat in America, NHANES 2001-2002: Usual Nutrient Intakes From Food Compared to Dietary Reference Intakes. Washington, DC: Department of Agriculture Agricultural Research Service (US); 2005. 
191. Kant AK. Consumption of energy-dense, nutrient-poor foods by adult Americans: nutritional and health implications. The Third National Health and Nutrition Examination Survey, 1988-1994. Am J Clin Nutr. 2000;72(4):929-936.

192. Rumm-Kreuter D, Demmel I. Comparison of vitamin losses in vegetables due to various cooking methods. J Nutr Sci Vitaminol (Tokyo). 1990;36 Suppl 1:S7-S14.

193. Kimura M, Itokawa Y. Cooking losses of minerals in foods and its nutritional significance. J Nutr Sci Vitaminol (Tokyo). 1990;36 Suppl 1:S25-S32.

194. Nursal B, Yücecan S. Vitamin C losses in some frozen vegetables due to various cooking methods. Nahrung. 2000;44(6):451-453.

195. McKillop DJ, Pentieva K, Daly D, et al. The effect of different cooking methods on folate retention in various foods that are amongst the major contributors to folate intake in the UK diet. Br J Nutr. 2002;88(6): 681-688.

196. Agte V, Tarwadi K, Mengale S, et al. Vitamin profile of cooked foods: how healthy is the practice of ready-to-eat foods? Int J Food Sci Nutr. 2002;53(3):197-208.

197. Jiménez-Monreal AM, García-Diz L, Martínez-Tomé M, et al. Influence of cooking methods on antioxidant activity of vegetables. J Food Sci. 2009;74(3):H97-H103.

198. Lykkesfeldt J, Christen S, Wallock LM, et al. Ascorbate is depleted by smoking and repleted by moderate supplementation: a study in male smokers and nonsmokers with matched dietary antioxidant intakes. Am J Clin Nutr. 2000;71(2):530-536.

199. Ames BN. Low micronutrient intake may accelerate the degenerative diseases of aging through allocation of scarce micronutrients by triage. Proc Natl Acad Sci U S A. 2006;103(47):17589-17594.

200. McCann JC, Ames BN. Vitamin K, an example of triage theory: is micronutrient inadequacy linked to diseases of aging? Am J Clin Nutr. 2009;90(4):889-907.

201. He K, Song Y, Belin RJ, Chen Y. Magnesium intake and the metabolic syndrome: epidemiologic evidence to date. J Cardiometab Syndr. 2006;1(5):351-355.

202. Ford ES, Li C, McGuire LC, et al. Intake of dietary magnesium and the prevalence of the metabolic syndrome among US adults. Obesity (Silver Spring). 2007;15(5):1139-1146.

203. Rylander R. Environmental magnesium deficiency as a cardiovascular risk factor. J Cardiovasc Risk. 1996;3:4-10.

204. Rubenowitz E, Molin I, Axelsson G, Rylander R. Magnesium in drinking water in relation to morbidity and mortality from acute myocardial infarction. Epidemiology. 2000;11:416-421.

205. Al-Delaimy WK, Rimm EB, Willett WC, et al. Magnesium intake and risk of coronary heart disease among men. J Am Coll Nutr. 2004;23(1): 63-70.

206. Nielsen FH, Milne DB, Klevay LM, et al. Dietary magnesium deficiency induces heart rhythm changes, impairs glucose tolerance, and decreases serum cholesterol in post menopausal women. $\mathrm{J} \mathrm{Am} \mathrm{Coll}$ Nutr. 2007;26(2):121-132.

207. Rosanoff A. Magnesium supplements may enhance the effect of antihypertensive medications in stage 1 hypertensive subjects. Magnes Res. 2010;23(1):27-40.

208. Hatzistavri LS, Sarafidis PA, Georgianos PI, et al. Oral magnesium supplementation reduces ambulatory blood pressure in patients with mild hypertension. Am J Hypertens. 2009;22(10): 1070-1075.

209. Hadjistavri LS, Sarafidis PA, Georgianos PI, et al. Beneficial effects of oral magnesium supplementation on insulin sensitivity and serum lipid profile. Med Sci Monit. 2010;16(6):CR307-CR312.

210. Geleijnse JM, Vermeer C, Grobbee DE, et al. Dietary intake of menaquinone is associated with a reduced risk of coronary heart disease: the Rotterdam Study. J Nutr. 2004;134(11):3100-3105.

211. Gast GC, de Roos NM, Sluijs I, et al. A high menaquinone intake reduces the incidence of coronary heart disease. Nutr Metab Cardiovasc Dis. 2009;19(7):504-510.
212. Beulens JW, Bots ML, Atsma F. High dietary menaquinone intake is associated with reduced coronary calcification. Atherosclerosis. 2009;203(2):489-493.

213. Corwin EJ. The concept of epigenetics and its role in the development of cardiovascular disease: commentary on "new and emerging theories of cardiovascular disease". Biol Res Nurs. 2004;6(1):11-16.

214. Matouk CC, Marsden PA. Epigenetic regulation of vascular endothelial gene expression. Circ Res. 2008;102:873-887.

215. Frassetto L, Morris RC Jr, Sellmeyer DE, et al. Diet, evolution and aging: the pathophysiologic effects of the post-agricultural inversion of the potassium-to-sodium and base-to-chloride ratios in the human diet. Eur J Nutr. 2001;40(5):200-213.

216. Ströhle A, Hahn A, Sebastian A. Latitude, local ecology, and huntergatherer dietary acid load: implications from evolutionary ecology. Am J Clin Nutr. 2010;92(4):940-945.

217. Jajoo R, Song L, Rasmussen H, et al. Dietary acid-base balance, bone resorption, and calcium excretion. J Am Coll Nutr. 2006;25(3): 224-230.

218. Rylander R, Remer T, Berkemeyer S, Vormann J. Acid-base status affects renal magnesium losses in healthy, elderly persons. J Nutr. 2006;136(9):2374-2377.

219. Frassetto LA, Morris RC Jr, Sebastian A. Dietary sodium chloride intake independently predicts the degree of hyperchloremic metabolic acidosis in healthy humans consuming a net acid-producing diet. Am J Physiol Renal Physiol. 2007;293(2):F521-F525.

220. Cani PD, Bibiloni R, Knauf C, et al. Changes in gut microbiota control metabolic endotoxemia-induced inflammation in high-fat diet-induced obesity and diabetes in mice. Diabetes. 2008;57(6): 1470-1481.

221. Cordain L, Toohey L, Smith MJ, Hickey MS. Modulation of immune function by dietary lectins in rheumatoid arthritis. Br J Nutr. 2000;83(3):207-217.

222. Erridge C, Attina T, Spickett CM, Webb DJ. A high-fat meal induces low-grade endotoxemia: evidence of a novel mechanism of postprandial inflammation. Am J Clin Nutr. 2007;86(5):1286-1292.

223. Creely SJ, McTernan PG, Kusminski CM, et al. Lipopolysaccharide activates an innate immune system response in human adipose tissue in obesity and type 2 diabetes. Am J Physiol Endocrinol Metab. 2007;292(3):E740-E747.

224. Monaco C, Paleolog E. Nuclear factor kappaB: a potential therapeutic target in atherosclerosis and thrombosis. Cardiovasc Res. 2004;61(4):671-682.

225. Hotamisligil GS. Inflammation and metabolic disorders. Nature. 2006;444(7121):860-867.

226. Deopurkar R, Ghanim H, Friedman J, et al. Differential effects of cream, glucose, and orange juice on inflammation, endotoxin, and the expression of Toll-like receptor-4 and suppressor of cytokine signalling-3. Diabetes Care. 2010;33(5):991-997.

227. Ghanim H, Abuaysheh S, Sia CL, et al. Increase in plasma endotoxin concentrations and the expression of Toll-like receptors and suppressor of cytokine signalling-3 in mononuclear cells after a high-fat, highcarbohydrate meal: implications for insulin resistance. Diabetes Care. 2009;32(12):2281-2287.

228. Ghanim H, Sia CL, Upadhyay M, et al. Orange juice neutralizes the proinflammatory effect of a high-fat, high-carbohydrate meal and prevents endotoxin increase and Toll-like receptor expression. Am J Clin Nutr. 2010;91(4):940-949.

229. Purohit V, Bode JC, Bode C, et al. Alcohol, intestinal bacterial growth, intestinal permeability to endotoxin, and medical consequences: summary of a symposium. Alcohol. 2008;42(5):349-361.

230. Patel B, Schutte R, Sporns P, et al. Potato glycoalkaloids adversely affect intestinal permeability and aggravate inflammatory bowel disease. Inflamm Bowel Dis. 2002;8(5):340-346.

231. Keukens EA, de Vrije T, van den Boom C, et al. Molecular basis of glycoalkaloid induced membrane disruption. Biochim Biophys Acta. 1995;1240(2):216-228. 
232. Gee JM, Wortley GM, Johnson IT, et al. Effects of saponins and glycoalkaloids on the permeability and viability of mammalian intestinal cells and on the integrity of tissue preparations in vitro. Toxicol In Vitro. 1996;10(2):117-128.

233. Alvarez JR, Torres-Pinedo R. Interactions of soybean lectin, soyasaponins, and glycinin with rabbit jejunal mucosa in vitro. Pediatr Res. 1982;16(9):728-731.

234. Chao AC, Nguyen JV, Broughall M, et al. Enhancement of intestinal model compound transport by DS-1, a modified Quillaja saponin. J Pharm Sci. 1998;87(11):1395-1399.

235. Story JA, LePage SL, Petro MS, et al. Interactions of alfalfa plant and sprout saponins with cholesterol in vitro and in cholesterol-fed rats. Am J Clin Nutr. 1984;39(6):917-929.

236. Drago S, El Asmar R, Di Pierro M, et al. Gliadin, zonulin and gut permeability: effects on celiac and non-celiac intestinal mucosa and intestinal cell lines. Scand J Gastroenterol. 2006;41(4):408-419.

237. Visser J, Rozing J, Sapone A, et al. Tight junctions, intestinal permeability, and autoimmunity: celiac disease and type 1 diabetes paradigms. Ann N Y Acad Sci. 2009;1165:195-205.

238. Bernardo D, Garrote JA, Fernández-Salazar L, et al. Is gliadin really safe for non-coeliac individuals? Production of interleukin 15 in biopsy culture from non-coeliac individuals challenged with gliadin peptides. Gut. 2007;56(6):889-890.

239. Rakhimova M, Esslinger B, Schulze-Krebs A, et al. In vitro differentiation of human monocytes into dendritic cells by peptic-tryptic digest of gliadin is independent of genetic predisposition and the presence of celiac disease. J Clin Immunol. 2009;29(1):29-37.

240. Doherty M, Barry RE. Gluten-induced mucosal changes in subjects without overt small-bowel disease. Lancet. 1981;1(8219):517-520.

241. Reichelt KL, Jensen D. IgA antibodies against gliadin and gluten in multiple sclerosis. Acta Neurol Scand. 2004;110(4):239-241.

242. Pengiran Tengah CD, Lock RJ, Unsworth DJ, Wills AJ. Multiple sclerosis and occult gluten sensitivity. Neurology. 2004;62(12):2326-2327.

243. Barbeau WE, Bassaganya-Riera J, Hontecillas R. Putting the pieces of the puzzle together: a series of hypotheses on the etiology and pathogenesis of type 1 diabetes. Med Hypotheses. 2007;68(3):607-619.

244. Michaëlsson G, Gerdén B, Hagforsen E, et al. Psoriasis patients with antibodies to gliadin can be improved by a gluten-free diet. $\mathrm{Br} J$ Dermatol. 2000;142(1):44-51.

245. Lidén M, Kristjánsson G, Valtýsdóttir S, Hällgren R. Gluten sensitivity in patients with primary Sjögren's syndrome. Scand J Gastroenterol. 2007;42(8):962-967.

246. Elkan AC, Sjöberg B, Kolsrud B, et al. Gluten-free vegan diet induces decreased LDL and oxidized LDL levels and raised atheroprotective natural antibodies against phosphorylcholine in patients with rheumatoid arthritis: a randomized study. Arthritis Res Ther. 2008;10(2):R34.

247. De Faire U, Frostegård J. Natural antibodies against phosphorylcholine in cardiovascular disease. Ann N Y Acad Sci. 2009;1173: 292-300.

248. Frostegård J, Tao W, Georgiades A, et al. Atheroprotective natural anti-phosphorylcholine antibodies of $\operatorname{IgM}$ subclass are decreased in Swedish controls as compared to non-Westernized individuals from New Guinea. Nutr Metab (Lond). 2007;4:7.

249. Kilpatrick DC, Pusztai A, Grant G, et al. Tomato lectin resists digestion in the mammalian alimentary canal and binds to intestinal villi without deleterious effects. FEBS Lett. 1985;185(2):299-305.

250. Grant G, More LJ, McKenzie NH, Pusztai A. The effect of heating on the haemagglutinating activity and nutritional properties of bean (Phaseolus vulgaris) seeds. J Sci Food Agric. 1982;33(12): 1324-1326.

251. Wang Q, Yu LG, Campbell BJ, et al. Identification of intact peanut lectin in peripheral venous blood. Lancet. 1998;352(9143):1831-1832.

252. Kamikubo Y, Dellas C, Loskutoff DJ, et al. Contribution of leptin receptor N-linked glycans to leptin binding. Biochem J. 2008;410(3): 595-604.
253. Muraille E, Pajak B, Urbain J, Leo O. Carbohydrate-bearing cell surface receptors involved in innate immunity: interleukin-12 induction by mitogenic and nonmitogenic lectins. Cell Immunol. 1999;191(1):1-9.

254. Sodhi A, Kesherwani V. Production of TNF-alpha, IL-1beta, IL-12 and IFN-gamma in murine peritoneal macrophages on treatment with wheat germ agglutinin in vitro: involvement of tyrosine kinase pathways. Glycoconj J. 2007;24(9):573-582.

255. Saja K, Chatterjee U, Chatterjee BP, Sudhakaran PR. Activation dependent expression of MMPs in peripheral blood mononuclear cells involves protein kinase A. Mol Cell Biochem. 2007;296(1-2): 185-192.

256. Dubois B, Peumans WJ, Van Damme EJ, et al. Regulation of gelatinase B (MMP-9) in leukocytes by plant lectins. FEBS Lett. 1998; 427(2):275-278.

257. Ohmori T, Yatomi Y, Wu Y, et al. Wheat germ agglutinin-induced platelet activation via platelet endothelial cell adhesion molecule-1: involvement of rapid phospholipase $\mathrm{C}$ gamma 2 activation by $\mathrm{Src}$ family kinases. Biochemistry. 2001;40(43):12992-13001.

258. Cordain L. Atherogenic potential of peanut oil-based monounsaturated fatty acids diets. Lipids. 1998;33(2):229-230.

259. Burr ML, Fehily AM, Gilbert JF, et al. Effects of changes in fat, fish, and fibre intakes on death and myocardial reinfarction: Diet And Reinfarction Trial (DART) [see comments]. Lancet. 1989;2:757-761.

260. Ness AR, Hughes J, Elwood PC, et al. The long-term effect of dietary advice in men with coronary disease: follow-up of the Diet And Reinfarction Trial (DART). Eur J Clin Nutr. 2002;56(6):512-518.

261. Kanková K. Diabetic threesome (hyperglycaemia, renal function and nutrition) and advanced glycation end products: evidence for the multiple-hit agent? Proc Nutr Soc. 2008;67(1):60-74.

262. Peppa M, Raptis SA. Advanced glycation end products and cardiovascular disease. Curr Diabetes Rev. 2008;4(2):92-100.

263. Uribarri J, Cai W, Peppa M, et al. Circulating glycotoxins and dietary advanced glycation endproducts: two links to inflammatory response, oxidative stress, and aging. J Gerontol A Biol Sci Med Sci. 2007;62(4): $427-433$

264. Uribarri J, Woodruff S, Goodman S, et al. Advanced glycation end products in foods and a practical guide to their reduction in the diet. J Am Diet Assoc. 2010;110(6):911-916.e12.

265. Cerami C, Founds H, Nicholl I, et al. Tobacco smoke is a source of toxic reactive glycation products. Proc Natl Acad Sci US A. 1997;94: $13915-13920$.

266. Cordain L, Eades MR, Eades MD. Hyperinsulinemic diseases of civilization: more than just Syndrome X. Comp Biochem Physiol A Mol Integr Physiol. 2003;136(1):95-112.

267. Reaven GM. The insulin resistance syndrome: definition and dietary approaches to treatment. Annu Rev Nutr. 2005;25:391-406.

268. Roberts CK, Liu S. Effects of glycemic load on metabolic health and type 2 diabetes mellitus. J Diabetes Sci Technol. 2009;3(4):697-704.

269. Brand-Miller J, Dickinson S, Barclay A, Allman-Farinelli M. Glycemic index, glycemic load, and thrombogenesis. Semin Thromb Hemost. 2009;35(1):111-118.

270. Barclay AW, Petocz P, McMillan-Price J, et al. Glycemic index, glycemic load, and chronic disease risk: a meta-analysis of observational studies. Am J Clin Nutr. 2008;87(3):627-637.

271. Larsen TM, Dalskov SM, van Baak M, et al. Diets with high or low protein content and glycemic index for weight-loss maintenance. N Engl J Med. 2010;363(22):2102-2113.

272. Thomas DE, Elliott EJ, Baur L. Low glycaemic index or low glycaemic load diets for overweight and obesity. Cochrane Database Syst Rev. 2007;3:CD005105

273. Melnik BC, Schmitz G. Role of insulin, insulin-like growth factor-1, hyperglycaemic food and milk consumption in the pathogenesis of acne vulgaris. Exp Dermatol. 2009;18(10):833-841.

274. Alas-Salvadó J, Farrés X, Luque X, et al. Effect of two doses of a mixture of soluble fibres on body weight and metabolic variables in overweight or obese patients: a randomised trial. Br J Nutr. 2008;99(6): 1380-1387. 
275. Tarini J, Wolever TM. The fermentable fibre insulin increases postprandial serum short-chain fatty acids and reduces freefatty acids and ghrelin in healthy subjects. Appl Physiol Nutr Metab. 2010;35(1):9-16.

276. Higginson J, Oettlé AG. Cancer incidence in the Bantu and "Cape Colored" races of South Africa: report of a cancer survey in the Transvaal (1953-1955). J Natl Cancer Inst. 1960;24:589-671.

277. Calder JF, Wachira MW, Van Sant T, et al. Diverticular disease, carcinoma of the colon and diet in urban and rural Kenyan Africans. Diagn Imaging Clin Med. 1980;42:23-28.

278. Mitchell BL, Lawson MJ, Davies M, et al. Volatile fatty acids in the human intestine: studies in surgical patients. Nutr Res. 1985;5: 1089-1092.

279. Singh N. Blockade of dendritic cell development by bacterial fermentation products butyrate and propionate through a transporter (Slc5a8)-dependent inhibition of histone deacetylases. J Biol Chem. 2010;285(36):27601-27608.

280. Peng L, Li ZR, Green RS, et al. Butyrate enhances the intestinal barrier by facilitating tight junction assembly via activation of AMPactivated protein kinase in Caco-2 cell monolayers. J Nutr. 2009;139: 1619-1625.

281. Lewis K, Lutgendorff F, Phan V, et al. Enhanced translocation of bacteria across metabolically stressed epithelia is reduced by butyrate. Inflamm Bowel Dis. 2010;16(7):1138-1148.

282. Johnson RJ, Segal MS, Sautin Y, et al. Potential role of sugar (fructose) in the epidemic of hypertension, obesity and the metabolic syndrome, diabetes, kidney disease, and cardiovascular disease. Am J Clin Nutr. 2007;86(4):899-906.

283. Ouyang X, Cirillo P, Sautin Y, et al. Fructose consumption as a risk factor for non-alcoholic fatty liver disease. J Hepatol. 2008;48(6): 993-999.

284. Holt SH, Miller JC, Petocz P. An insulin index of foods: the insulin demand generated by $1000-\mathrm{kJ}$ portions of common foods. Am J Clin Nutr. 1997;66(5):1264-1276.

285. Ostman EM, Liljeberg Elmståhl HG, Björck IM. Inconsistency between glycemic and insulinemic responses to regular and fermented milk products. Am J Clin Nutr. 2001;74:96-100.

286. Liljeberg Elmstahl H, Bjorck I. Milk as a supplement to mixed meals may elevate postprandial insulinaemia. Eur J Clin Nutr. 2001;55: 994-999.

287. Hoyt G, Hickey MS, Cordain L. Dissociation of the glycaemic and insulinaemic responses to whole and skimmed milk. Br J Nutr. 2005;93(2):175-177.

288. Hoppe C, Mølgaard C, Vaag A, et al. High intakes of milk, but not meat increases insulin and insulin resistance in 8-year-old boys. Eur J Clin Nutr. 2005;59(3):393-398.

289. Pereira MA, Jacobs DR Jr, Van Horn L, et al. Dairy consumption, obesity, and the insulin resistance syndrome in young adults: the CARDIA study. JAMA. 2002;287(16):2081-2089.

290. Azadbakht L, Mirmiran P, Esmaillzadeh A, Azizi F. Dairy consumption is inversely associated with the prevalence of the metabolic syndrome in Tehranian adults. Am J Clin Nutr. 2005;82(3):523-530.

291. Liu S, Song Y, Ford ES, et al. Dietary calcium, vitamin D, and the prevalence of metabolic syndrome in middle-aged and older US women. Diabetes Care. 2005;28(12):2926-2932.

292. Lawlor DA, Ebrahim S, Timpson N, Davey Smith G. Avoiding milk is associated with a reduced risk of insulin resistance and the metabolic syndrome: findings from the British Women's Heart and Health Study. Diabet Med. 2005;22(6):808-811.

293. Almon R, Alvarez-Leon EE, Engfeldt P, et al. Associations between lactase persistence and the metabolic syndrome in a cross-sectional study in the Canary Islands. Eur J Nutr. 2010;49(3):141-146.

294. Ma B, Lawson AB, Liese AD, et al. Dairy, magnesium, and calcium intake in relation to insulin sensitivity: approaches to modeling a dosedependent association. Am J Epidemiol. 2006;164(5):449-458.

295. Melnik BC. Milk: the promoter of chronic Western diseases. Med Hypotheses. 2009;72(6):631-639.
296. Aranda P, Sanchez L, Perez MD, et al. Insulin in bovine colostrum and milk: evolution throughout lactation and binding to caseins. J Dairy Sci. 1991;74(12):4320-4325.

297. Collier RJ, Miller MA, Hildebrandt JR, et al. Factors affecting insulin-like growth factor-I concentration in bovine milk. J Dairy Sci. 1991;74: 2905-2911.

298. Bastian SE, Tao W, Georgiades A, et al. Measurement of betacellulin levels in bovine serum, colostrum and milk. JEndocrinol. 2001;168(1): 203-212.

299. Farlow DW, Xu X, Veenstra TD. Quantitative measurement of endogenous estrogen metabolites, risk factors for development of breast cancer, in commercial milk products by LC-MS/MS. J Chromatogr B Analyt Technol Biomed Life Sci. 2009;877(13): 1327-1334.

300. Danby FW.Acne, dairy and cancer: the 5alpha-P link. Dermatoendocrinol. 2009;1(1):12-16.

301. Kirkwood TB. Understanding ageing from an evolutionary perspective. J Intern Med. 2008 Feb;263(2):117-127.

302. Bunn HF, Higgins PJ. Reaction of monosaccharides with proteins: possible evolutionary significance. Science. 1981;213:222-2224.

303. Takeuchi M, Iwaki M, Takino J, et al. Immunological detection of fructose-derived advanced glycation end-products. Lab Invest. 2010;90(7):1117-1127.

304. National Academy of Sciences. Dietary Reference Intakes: The Essential Guide to Nutrient Requirements. 1st ed. Washington, DC: National Academy Press; 2006.

305. Campbell B, Kreider RB, Ziegenfuss T, et al. International Society of Sports Nutrition position stand: protein and exercise. J Int Soc Sports Nutr. 2007;4:8.

306. Dreyer HC, Volpi E. Role of protein and amino acids in the pathophysiology and treatment of sarcopenia. J Am Coll Nutr. 2005;24(2):140S-145S.

307. Kerstetter JE, Gaffney ED, O'Brien O. Dietary protein increases intestinal calcium absorption and improves bone balance: an hypothesis. In: Burckhardt P, Heaney R, Dawson-Hughes B, editors. Proceedings of the International Symposium on Nutritional Aspects of Osteoporosis, May 4-6, 2006. Lausanne, Switzerland. Elsevier; 2007:204-216.

308. Dawson-Hughes B. Protein intake and calcium absorption: potential role of the calcium sensor receptor. In: Burckhardt P, Heaney R, Dawson-Hughes B, editors. Proceedings of the International Symposium on Nutritional Aspects of Osteoporosis, May 4-6, 2006. Lausanne, Switzerland. Elsevier; 2007:217-227.

309. Hunt JR, Johnson LK, Fariba Roughead ZK. Dietary protein and calcium interact to influence calcium retention: a controlled feeding study. Am J Clin Nutr. 2009;89:1357-1365.

310. Sebastian A. Dietary protein content and the diet's net acid load: opposing effects on bone health. Am J Clin Nutr. 2005;82(5):921-922.

311. Westerterp-Plantenga MS, Nieuwenhuizen A, Tome D, et al. Dietary protein, weight loss, and weight maintenance. Annu Rev Nutr. 2009;29: 21-41.

312. Hodgson JM, Burke V, Beilin LJ, Puddey IB. Partial substitution of carbohydrate intake with protein intake from lean red meat lowers blood pressure in hypertensive persons. Am J Clin Nutr. 2006;83(4): 780-787.

313. Skov AR, Toubro S, Bulow J, et al. Changes in renal function during weight loss induced by high vs low-protein low-fat diets in overweight subjects. Int J Obes Relat Metab Disord. 1999;23(11):1170-1177.

314. Wrone EM, Carnethon MR, Palaniappan L, Fortmann SP. Association of dietary protein intake and microalbuminuria in healthy adults: Third National Health and Nutrition Examination Survey. Am J Kidney Dis. 2003;41(3):580-587.

315. Knight EL, Stampfer MJ, Hankinson SE, et al. The impact of protein intake on renal function decline in women with normal renal function or mild renal insufficiency. Ann Intern Med. 2003;138: 460-467.

316. Martin WF, Armstrong LE, Rodriguez NR. Dietary protein intake and renal function. Nutr Metab (Lond). 2005;2:25. 
317. Westman EC, Feinman RD, Mavropoulos JC, et al. Low-carbohydrate nutrition and metabolism. Am J Clin Nutr. 2007;86(2):276-284.

318. Volek JS, Fernandez ML, Feinman RD, et al. Dietary carbohydrate restriction induces a unique metabolic state positively affecting atherogenic dyslipidemia, fatty acid partitioning, and metabolic syndrome. Prog Lipid Res. 2008;47:307-318.

319. Simopoulos AP. The Mediterranean diets: what is so special about the diet of Greece? The scientific evidence. J Nutr. 2001;131:3065S-3073S.

320. Mensink RP, Zock PL, Kester AD, Katan MB. Effects of dietary fatty acids and carbohydrates on the ratio of serum total to HDL cholesterol and on serum lipids and apolipoproteins: a meta-analysis of 60 controlled trials. Am J Clin Nutr. 2003;77(5):1146-1155.

321. Carluccio MA, Massaro M, Scoditti E, De Caterina R. Vasculoprotective potential of olive oil components. Mol Nutr Food Res. 2007;51(10):1225-1234.

322. Cicerale S, Lucas L, Keast R. Biological activities of phenolic compounds present in virgin olive oil. Int J Mol Sci. 2010;11(2): 458-479.

323. Clarke R, Frost C, Collins R, et al. Dietary lipids and blood cholesterol: quantitative meta-analysis of metabolic ward studies. BMJ. 1997;314: 112-117.

324. Siri-Tarino PW, Sun Q, Hu FB, Krauss RM. Saturated fatty acids and risk of coronary heart disease: modulation by replacement nutrients Curr Atheroscler Rep. 2010;12(6):384-390.

325. Siri-Tarino PW, Sun Q, Hu FB, Krauss RM. Meta-analysis of prospective cohort studies evaluating the association of saturated fat with cardiovascular disease. Am J Clin Nutr. 2010;91(3):535-546.

326. Jakobsen MU, Dethlefsen C, Joensen AM, et al. Intake of carbohydrates compared with intake of saturated fatty acids and risk of myocardial infarction: importance of the glycemic index. Am J Clin Nutr. 2010;91(6):1764-1768

327. Stanhope JM, Sampson VM, Prior IA. The Tokelau Island Migrant Study: serum lipid concentration in two environments. J Chronic Dis. 1981;34(2-3):45-55.

328. Forsythe CE, Phinney SD, Fernandez ML, et al. Comparison of low fat and low carbohydrate diets on circulating fatty acid composition and markers of inflammation. Lipids. 2008 Jan;43(1):65-77.

329. Assunção ML, Ferreira HS, dos Santos AF, et al. Effects of dietary coconut oil on the biochemical and anthropometric profiles of women presenting abdominal obesity. Lipids. 2009;44(7):593-601.

330. Nevin KG, Rajamohan T. Beneficial effects of virgin coconut oil on lipid parameters and in vitro LDL oxidation. Clin Biochem. 2004;37(9):830-835.

331. Müller H, Lindman AS, Blomfeldt A, et al. A diet rich in coconut oil reduces diurnal postprandial variations in circulating tissue plasminogen activator antigen and fasting lipoprotein (a) compared with a diet rich in unsaturated fat in women. $J$ Nutr. 2003;133(11):3422-3427.
332. Pella D, Dubnov G, Singh RB, et al. Effects of an Indo-Mediterranean diet on the omega-6/omega-3 ratio in patients at high risk of coronary artery disease: the Indian paradox. World Rev Nutr Diet. 2003;92: 74-80.

333. Dubnov G, Berry EM. Omega-6/omega-3 fatty acid ratio: the Israeli paradox. World Rev Nutr Diet. 2003;92:81-91.

334. Ramsden CE, Hibbeln JR, Lands WE. Letter to the Editor re: linoleic acid and coronary heart disease. Prostaglandins Leukot Essent Fatty Acids. 2009;80(1):77.

335. Harris WS. The omega-3 index: clinical utility for therapeutic intervention. Curr Cardiol Rep. 2010;12(6):503-508.

336. Calder PC. The 2008 ESPEN Sir David Cuthbertson Lecture. Fatty acids and inflammation: from the membrane to the nucleus and from the laboratory bench to the clinic. Clin Nutr. 2010;29(1): $5-12$.

337. Ramsden CE, Hibbeln JR, Majchrzak SF, Davis JM. N-6 fatty acidspecific and mixed polyunsaturate dietary interventions have different effects on CHD risk: a meta-analysis of randomised controlled trials. Br J Nutr. 2010;104(11):1586-1600.

338. De Lorgeril M, Renaud S, Mamelle N, et al. Mediterranean alphalinolenic acid-rich diet in secondary prevention of coronary heart disease. Lancet. 1994;343(8911):1454-1459.

339. Muskiet FAJ. Pathophysiology and evolutionary aspects of dietary fats and long-chain polyunsaturated fatty acids across the life cycle. In: Montmayeur JP, le Coutre J, editors. Fat Detection: Taste, Texture, and Post Ingestive Effects. Boca Raton, FL: CRC Press; 2010: 19-79.

340. Serhan CN. Novel lipid mediators and resolution mechanisms in acute inflammation: to resolve or not? Am J Pathol. 2010;177(4):1576-15791.

341. Lindeberg S, Jönsson T, Granfeldt Y, et al. A Palaeolithic diet improves glucose tolerance more than a Mediterranean-like diet in individuals with ischaemic heart disease. Diabetologia. 2007;50(9): 1795-1807.

342. Jönsson T, Granfeldt Y, Ahrén B, et al. Beneficial effects of a Paleolithic diet on cardiovascular risk factors in type 2 diabetes: a randomized cross-over pilot study. Cardiovasc Diabetol. 2009;8:35.

343. Jönsson T, Ahrén B, Pacini G, et al. A Paleolithic diet confers higher insulin sensitivity, lower C-reactive protein and lower blood pressure than a cereal-based diet in domestic pigs. Nutr Metab (Lond) 2006;3:39.
Research Reports in Clinical Cardiology

\section{Publish your work in this journal}

Research Reports in Clinical Cardiology is an international, peerreviewed, open access journal publishing original research, reports, editorials, reviews and commentaries on all areas of cardiology in the clinic and laboratory. The manuscript management system is completely online and includes a very quick and fair peer-review system.

\section{Dovepress}

Visit http://www.dovepress.com/testimonials.php to read real quotes from published authors. 